\title{
Clay Minerals Change the Toxic Effect of Cadmium on the Activities of Leucine Aminopeptidase
}

\author{
Shunyu Huang, Jingji Li $(D$, and Jipeng Wang \\ State Key Laboratory of Geohazard Prevention and Geoenvironment Protection, Chengdu University of Technology, \\ 610059 Chengdu, China \\ Correspondence should be addressed to Jingji Li; lijingji2014@cdut.edu.cn
}

Received 10 June 2021; Accepted 4 October 2021; Published 22 October 2021

Academic Editor: Qiaohui Fan

Copyright (c) 2021 Shunyu Huang et al. This is an open access article distributed under the Creative Commons Attribution License, which permits unrestricted use, distribution, and reproduction in any medium, provided the original work is properly cited.

\begin{abstract}
Soil leucine aminopeptidase (LAP) is a hydrolytic enzyme involved in the acquisition of nitrogen by microorganisms. In contaminated soils, LAP activity is affected not only by the type and concentration of heavy metals but also by the form of enzyme. Here, we investigated the degree and mechanism of cadmium (Cd) inhibition of soil LAP and purified LAP. We also examined the effect of montmorillonite and kaolinite on LAP and LAP contaminated with Cd. The results showed that Cd inhibition of LAP activity increased with increasing Cd concentration and that Cd exerted noncompetitive inhibition of LAP. The addition of clay minerals decreases LAP activity and the maximum reaction rate $\left(V_{\max }\right)$, regardless of the presence of Cd. Montmorillonite decreases the affinity of LAP to the substrate $\left(K_{m}\right)$, while kaolinite increases the affinity of LAP to the substrate. The clay mineral-immobilized LAP showed an increase in resistance to Cd contamination compared with the free LAP. The results obtained in this study may aid in understanding the toxic effects of heavy metals on soil enzymes.
\end{abstract}

\section{Introduction}

Cadmium (Cd) has become one of the most hazardous heavy metals in soil as a result of its potential, persistent, and irreversible toxicity [1-3]. When Cd enters soil, it affects the environmental health of the soil and the stability of ecosystem, particularly soil microorganisms [4, 5]. Soil microorganisms are the most active and sensitive component of the soil ecosystem and can secrete most soil extracellular enzymes associated with the soil nutrient cycle $[6,7]$. Since soil enzyme activity is closely related to soil microorganisms and is sensitive to changes in environmental conditions, soil enzyme activity is often used as an indicator to evaluate the level to which heavy metals influence soil microbial function and soil ecosystem health [8-12].

According to previous studies, the soil enzyme activity exponentially decreases with increasing heavy metal concentrations by displacing enzyme conformation-related metals and occupying the active center of the enzyme or by binding to sulfhydryl, amino, and carboxyl groups in the enzyme structure to reduce the active site of the enzyme [13-16].
However, the extent of soil enzyme activity in response to heavy metals is related not only to the type and concentration of heavy metals but also to the type of soil enzyme and soil properties, such as clay mineral content $[17,18]$. Clay minerals form enzyme complexes whose molecular structure and catalytic properties differ from those of free enzymes, thus affecting the contact of enzymes with heavy metals and substrates [19-21]. At the same time, heavy metals can interact with clay mineral surfaces and compete with enzymes to form heavy metal-enzyme-clay mineral complexes $[22,23]$. Therefore, free enzymes, soil enzymes, and enzymes immobilized by clay minerals have different response to heavy metal pollution.

Leucine aminopeptidase (LAP, Enzyme Commission number: 3.4.11.1) catalyzes the hydrolysis of leucine and other hydrophobic amino acids at the N-terminus of polypeptides. It is one kind of enzyme involved in the microbial acquisition of $\mathrm{N}$ in soil [6]. Cd acts as an enzyme inhibitor by replacing the metal associated with the active center of phosphatase [24, 25]. Additionally, soil properties (e.g., organic $\mathrm{C}$, total $\mathrm{N}, \mathrm{pH}$, soil particle size, and clay contents) 


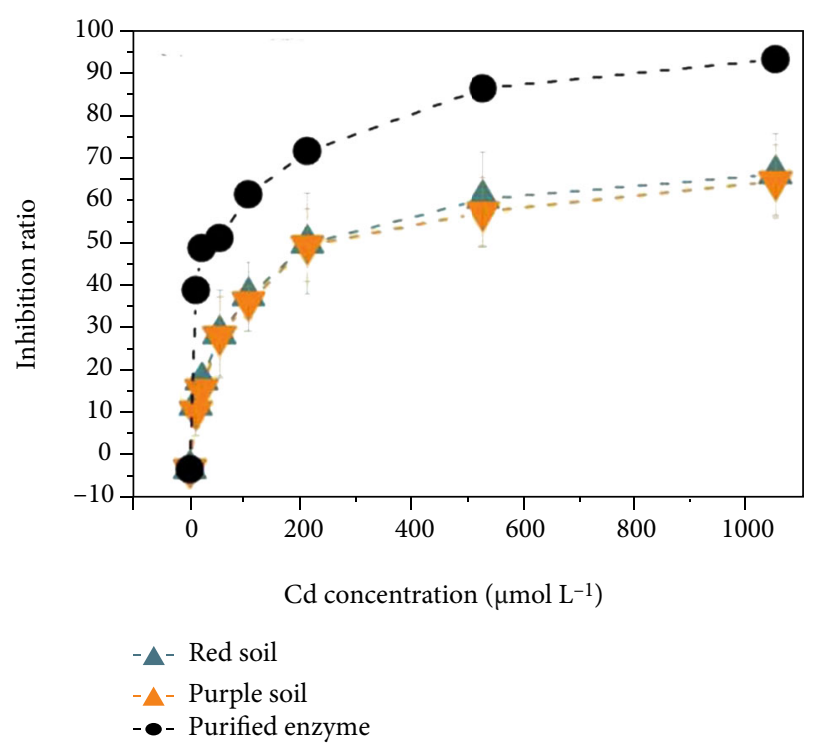

(a)

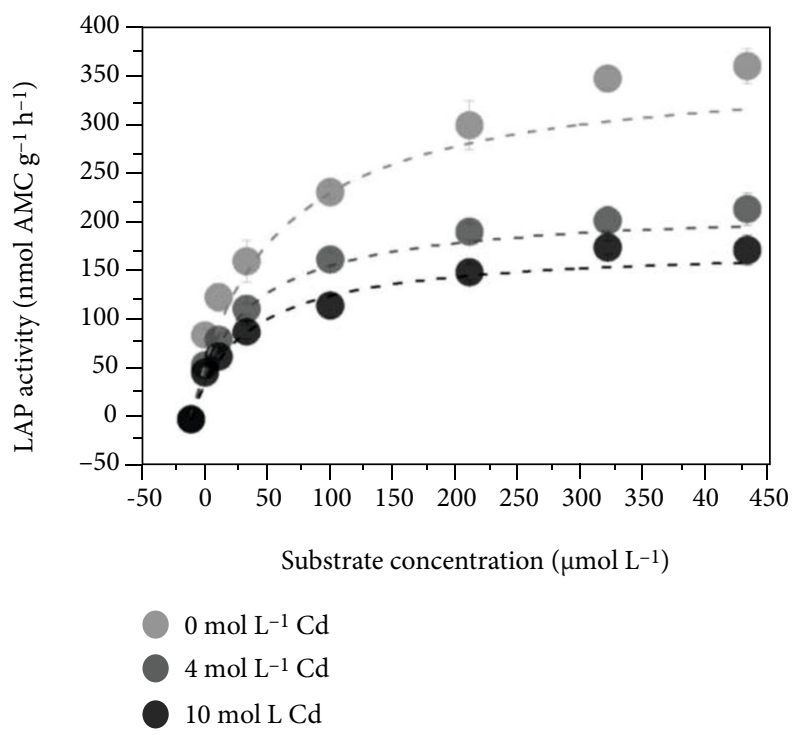

(c)

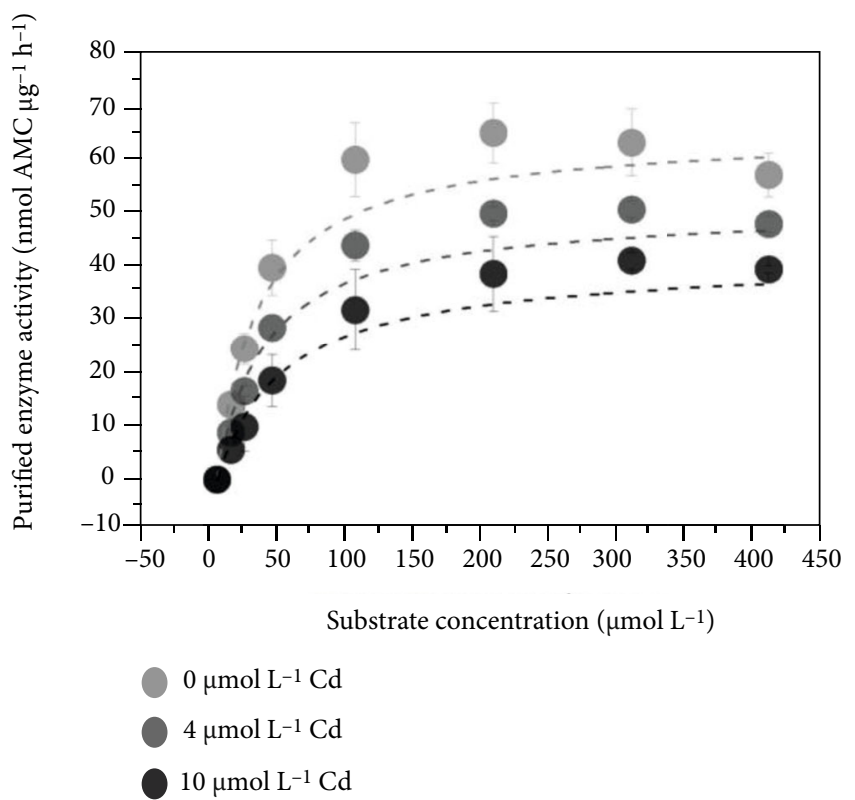

(b)

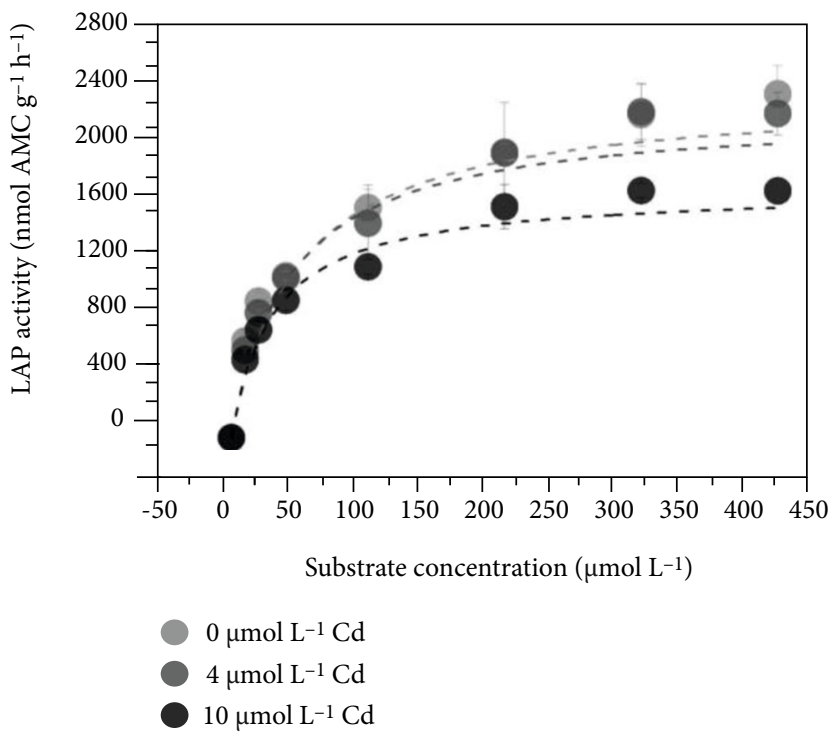

(d)

FIgURE 1: Effect of Cd on the inhibition rate and kinetic constants of LAP: (a) inhibition rate of soil LAP and purified LAP by different concentrations of Cd; (b) kinetic curve of purified enzyme affected by Cd; (c) kinetic curve of LAP in red soil affected by Cd; (d) kinetic curve of LAP in purple soil affected by Cd.

can influence the toxicity of heavy metals in soil on soil enzymes [26]. On this basis, we anticipated that the inhibition of LAP by $\mathrm{Cd}$ may be due to the displacement of enzyme conformation-related metals and occupation of the active center of the enzyme; thus, the interaction of clay minerals with LAP might contribute to different Cd toxicity on free LAP, soil LAP, and immobilized LAP. It has been demonstrated that $\mathrm{Cd}$ shows exponential or logarithmic inhibition of other hydrolytic enzymes, such as phosphatase and $\beta$-glucosidase $[27,28]$. However, the toxicity of $\mathrm{Cd}$ to LAP is poorly researched in existing studies, and there is barely any information available on the effects of the interaction between clay minerals and LAP on Cd toxicity.
Consequently, we investigated the effect of Cd toxicity on the degree of LAP exposure (free LAP, LAP in soil, and LAP immobilized by clay minerals). A preliminary attempt was also made to investigate the reasons of cadmium toxicity to LAP (with reference to the toxicity of other heavy metals to LAP and experiments on the recovery of activity of CdLAP in the presence of $\mathrm{Mg}$ and $\mathrm{Mn}$ addition) in an attempt to reach the following conclusions: (1) the difference response between free LAP, soil LAP, and clay mineralimmobilized LAP on Cd toxicity and (2) the mechanism of LAP inhibition by $\mathrm{Cd}$.

Our work is a preliminary investigation into the mechanisms of Cd contamination on LAP (soil LAP and purified 
TABLE 1: Changes in the kinetic constants $\left(V_{\max }\right.$ and $\left.K_{m}\right)$ of LAP by different concentrations of Cd.

\begin{tabular}{|c|c|c|c|c|c|c|c|c|c|}
\hline & \multicolumn{3}{|c|}{ Purified enzyme } & \multicolumn{3}{|c|}{ Red soil } & \multicolumn{3}{|c|}{ Purple soil } \\
\hline & $0 \mu \mathrm{mol} \mathrm{L}{ }^{-1}$ & $4 \mu \mathrm{mol} \mathrm{L}{ }^{-1}$ & $10 \mu \mathrm{mol} \mathrm{L}^{-1}$ & $0 \mu \mathrm{mol} \mathrm{L}^{-1}$ & $4 \mu \mathrm{mol} \mathrm{L}^{-1}$ & $10 \mu \mathrm{mol} \mathrm{L}^{-1}$ & $0 \mu \mathrm{mol} \mathrm{L}-1$ & $4 \mu \mathrm{mol} \mathrm{L}^{-1}$ & $10 \mu \mathrm{mol} \mathrm{L}^{-1}$ \\
\hline$\overline{V_{\text {max }}}$ & $64.88^{\mathrm{A}}$ & $50.58^{\mathrm{B}}$ & $41.06^{\mathrm{C}}$ & $327.56^{\mathrm{A} \prime}$ & $194.93^{\mathrm{B} \prime}$ & $159.41^{\mathrm{C} /}$ & $2167.45^{\mathrm{A} \prime \prime}$ & $2054.84^{\mathrm{A} / \prime}$ & $1558.41^{\mathrm{B} / 1}$ \\
\hline$K_{m}$ & $30.43^{\mathrm{a}}$ & $34.65^{\mathrm{a}}$ & $49.05^{\mathrm{a}}$ & $55.73^{\mathrm{a}^{\prime}}$ & $36.22^{\mathrm{a}^{\prime}}$ & $38.72^{\mathrm{a}^{\prime}}$ & $48.81^{\mathrm{a} / \prime}$ & $43.27^{\mathrm{a} \prime \prime}$ & $30.69^{\mathrm{a} / \prime}$ \\
\hline$R^{2}$ & 0.96 & 0.97 & 0.97 & 0.97 & 0.99 & 0.97 & 0.97 & 0.99 & 0.97 \\
\hline
\end{tabular}

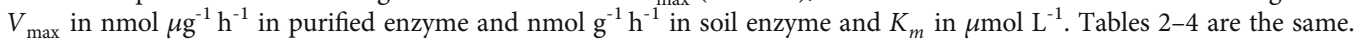

LAP) and the role that clay minerals play in this process. This provides a theoretical basis for restoring the activity and function of LAP in Cd-contaminated soils, as well as providing some assistance in restoring nitrogen use efficiency and accelerating nitrogen cycling in contaminated soils.

\section{Material and Methods}

2.1. Purified Enzyme and Soils. The purified enzyme was purchased from Sigma-Aldrich (product number: L5006, Type IV-S, stored as ammonium sulfate suspension at $4^{\circ} \mathrm{C}$ ) and volumed with $2.5 \mathrm{~mol} \mathrm{~L}^{-1}\left(\mathrm{NH}_{4}\right)_{2} \mathrm{SO}_{4}$ to $5 \mathrm{~mL}$ to make an enzyme stock solution. The enzyme stock solution was stored at $4^{\circ} \mathrm{C}$. To make activated enzyme, the enzyme stock solution was diluted with $50 \mathrm{mmol} \mathrm{L}^{-1} \mathrm{pH} 8 \mathrm{THAM}$ and activated at $37^{\circ} \mathrm{C}$ for 2 hours before use.

The soils used in this study are red soil and purple soil, which were collected from the Ecological Experimental Station of Red Soil in Jiangxi, China $\left(28^{\circ} 15^{\prime} \mathrm{N}, 116^{\circ} 55^{\prime} \mathrm{E}\right)$ and Yanting Station of Chinese Ecosystem Research Network $(\mathrm{CERN})$ in Sichuan, China $\left(31^{\circ} 16^{\prime} \mathrm{N}, 105^{\circ} 27^{\prime} \mathrm{E}\right)$, respectively. Soil samples were sieved $(<2 \mathrm{~mm})$ and stored at $4^{\circ} \mathrm{C}$ until enzyme assay.

Soil $\mathrm{pH}$, particle size, organic $\mathrm{C}$, and total $\mathrm{N}$ were determined using air-dried soils. The $\mathrm{pH}$ was determined using a $1: 2.5$ ratio between the mass of the soil sample and the volume of deionized water. Soil samples were pretreated with $30 \% \mathrm{H}_{2} \mathrm{O}_{2}$ and $10 \% \mathrm{HCl}$ to remove organic matter and carbonates, and $0.05 \mathrm{~mol} \mathrm{~L}^{-1}$ sodium hexametaphosphate was added to disperse the soil aggregates for particle size distribution analysis by Malvern MS 2000 (Malvern Instruments, Malvern, England). The organic $\mathrm{C}$ and total $\mathrm{N}$ of the soil were determined by using $0.5 \mathrm{~mol} \mathrm{~L}^{-1} \mathrm{HCl}$ to remove carbonates and then analyzed by an element analyzer (Elementar vario MACRO cube, Germany) (Table S1).

\subsection{Clay Mineral and Immobilized LAP. Montmorillonite} $\left((\mathrm{Al}, \mathrm{Mg})_{2}\left[\mathrm{Si}_{4} \mathrm{O}_{10}\right](\mathrm{OH})_{2} \cdot \mathrm{nH}_{2} \mathrm{O}\right)$ and kaolinite $\left(\mathrm{Al}_{4}\left[\mathrm{Si}_{4} \mathrm{O}_{10}\right]\right.$ $(\mathrm{OH})_{8}$ ) were purchased from Aladdin (product numbers M141491 and K100134, respectively) (Table S2). The surface morphology of clay minerals was analyzed by scanning electron microscopy (SEM) (Thermo Prisma E, Finland) at $20 \mathrm{kV}$ and at a magnification of $3500 \mathrm{x}$ (Figure S1). The particle size distribution was determined by a Malvern ZEN 3600 (Malvern Instruments, Malvern, England). The specific surface area (SSA) of clay minerals was analyzed by the $\mathrm{N}_{2}$ adsorption method $[29,30]$.
Clay mineral colloid solution $\left(0.5 \mathrm{mg} \mathrm{mL}^{-1}\right)$ was prepared by adding $25 \mathrm{mg}$ montmorillonite or kaolinite to $50 \mathrm{~mL}$ $50 \mathrm{mmol} \mathrm{L}^{-1} \mathrm{pH} 8$ THAM into a $150 \mathrm{~mL}$ beaker and performing ultrasonication for 5 minutes. The activated enzyme was diluted 2500 times using THAM to prepare the LAP working solution. To prepare clay mineral-immobilized LAP, $20 \mathrm{~mL}$ of montmorillonite or kaolinite colloids was added to $20 \mathrm{~mL}$ of the LAP working solution. The suspension was stirred for 30 minutes at $250 \mathrm{rmin}^{-1}$ at $25^{\circ} \mathrm{C}$ before centrifugation at $8000 \mathrm{r} \mathrm{min}^{-1}$ for 5 minutes. The residue was washed with $40 \mathrm{~mL}$ deionized (DI) water and centrifuged twice to remove the unabsorbed LAP. Finally, the residue was resuspended in $40 \mathrm{~mL}$ of $50 \mathrm{mmol} \mathrm{L}^{-1} \mathrm{pH} 8$ THAM buffer. The clay mineral-immobilized LAP was mixed thoroughly before being added to a 96-well plate.

\subsection{Experimental Design}

2.3.1. Enzyme Assay. L-leucine-7-amido-4-methylcoumarin (L-leucine-AMC) and 7-amino-4-methyl-coumarin (AMC) were purchased from Aladdin and used as the substrate and the standard for LAP in microplate fluorimetric assays, respectively.

The soil LAP activity was determined as previously described [31, 32]. Briefly, a soil homogenate was prepared by stirring $0.5 \mathrm{~g}$ fresh soil and $120 \mathrm{~mL}$ DI water at $600 \mathrm{rpm}$ for 30 minutes. Then, the homogenate was placed into the assay well (including $50 \mu \mathrm{L}$ THAM buffer, $100 \mu \mathrm{L}$ homogenate, and $50 \mu \mathrm{L}$ L-leucine-AMC) and quenched well (including $50 \mu \mathrm{L}$ THAM buffer, $100 \mu \mathrm{L}$ homogenate, and $50 \mu \mathrm{L}$ AMC). DI water was used in place of homogenate in a standard well (including $50 \mu \mathrm{L}$ THAM buffer, $100 \mu \mathrm{L}$ DI water, and $50 \mu \mathrm{L} A M C$ ) and substrate control well (including $50 \mu \mathrm{L}$ THAM buffer, $100 \mu \mathrm{L}$ DI water, and $50 \mu \mathrm{L}$ L-leucineAMC). THAM, AMC, and L-leucine-AMC were then added sequentially according to the type of well. The THAM concentration in all wells was $20 \mathrm{mmol} \mathrm{L}^{-1}$, and the L-leucineAMC was $200 \mu \mathrm{mol} \mathrm{L}^{-1}$. The concentration of AMC was $10 \mu \mathrm{mol} \mathrm{L}^{-1}$ before being added. The mixture in 96-well plates was incubated for $1 \mathrm{~h}$ at $37^{\circ} \mathrm{C}$ before being read by a fluorometer (Thermo Varioskan ${ }^{\mathrm{TM}}$ LUX, Finland) with $365 \mathrm{~nm}$ excitation and a $450 \mathrm{~nm}$ emission filter immediately.

For the purified enzyme and immobilized enzyme, the soil homogenate in the above method was replaced with the LAP working solution and clay mineral-immobilized enzyme LAP, respectively. The purified enzyme was incubated and measured under the same conditions as the soil. 

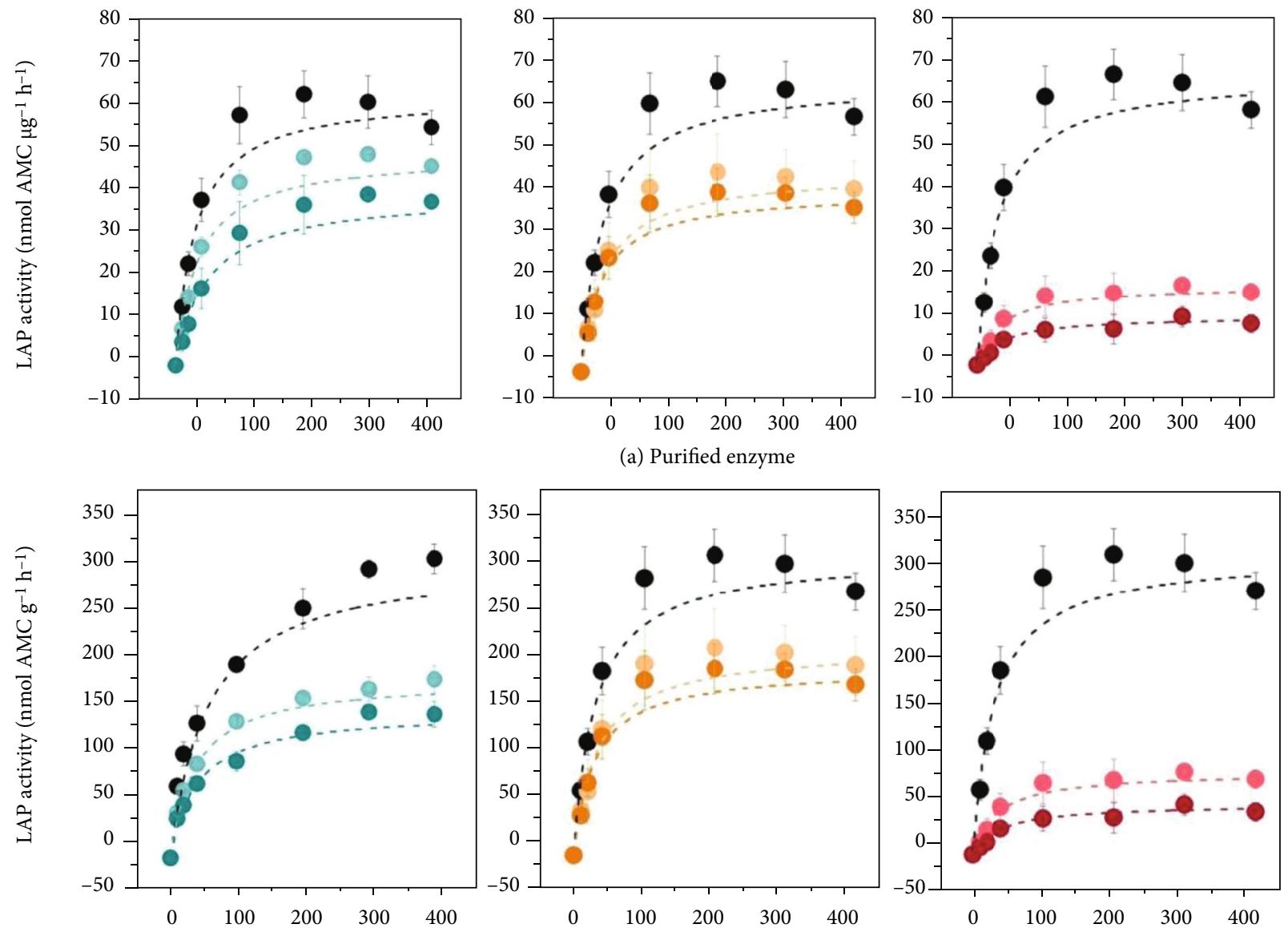

(b) Red soil

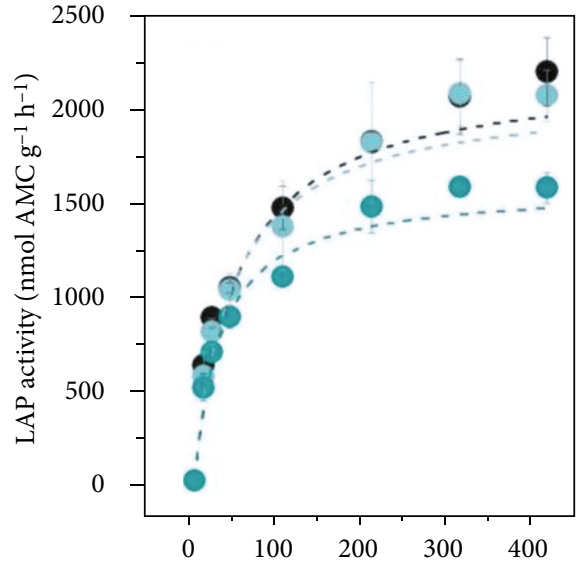

Subtstrate concentration $\left(\mu \mathrm{mol} \mathrm{L}{ }^{-1}\right)$

$0 \mu \mathrm{mol} \mathrm{L}-1 \mathrm{Cd}$

$4 \mu \mathrm{mol} \mathrm{L}{ }^{-1} \mathrm{Cd}$

$10 \mu \mathrm{mol} \mathrm{L}{ }^{-1} \mathrm{Cd}$

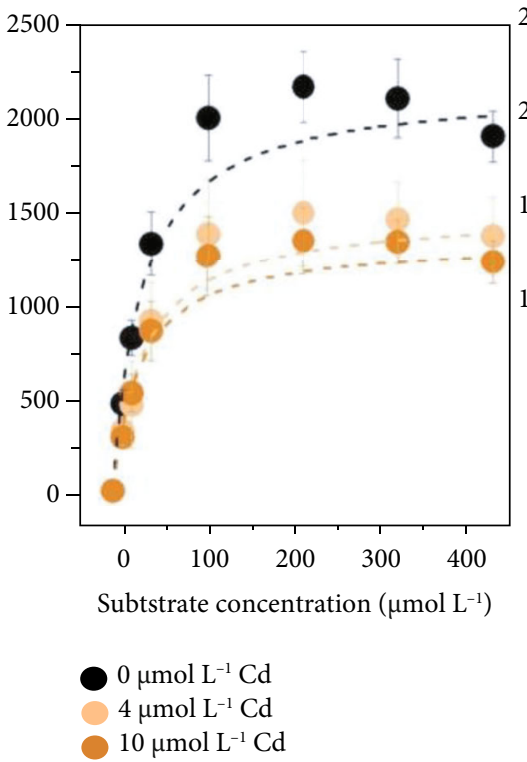

(c) Purple soil

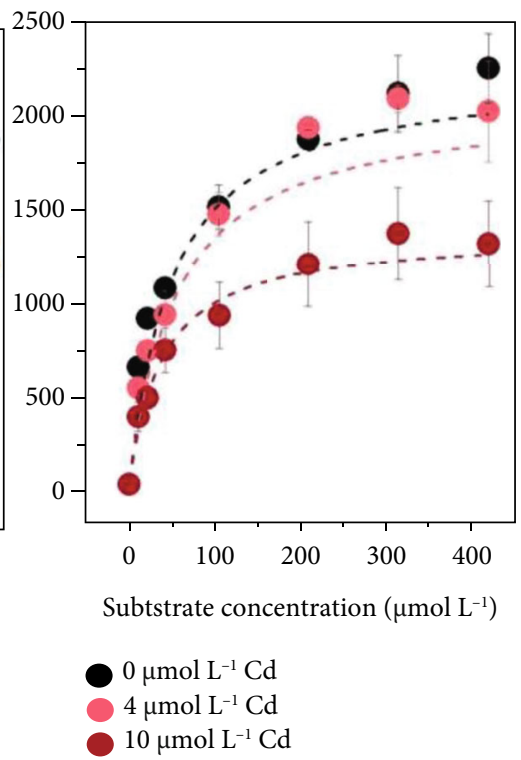

FIgURE 2: Kinetic profiles of purified enzyme, red soil LAP, and purple soil LAP affected by 0, 4, and $10 \mu \mathrm{mol} \mathrm{Cd,} \mathrm{Ag,} \mathrm{and} \mathrm{Hg,} \mathrm{respectively.}$

2.3.2. Effect of Clay Minerals on LAP. For soil LAP, the effect of clay mineral addition on Cd toxicity was investigated in the natural state ( $0 \mathrm{mg}$ clay mineral addition), low concentration $(50 \mathrm{mg}$ montmorillonite or kaolinite per gram fresh soil), and high concentration (100 mg montmorillonite or kaolinite per gram fresh soil). Clay minerals are added by mixing the corresponding quality and type of clay minerals with red and purple soil to produce homogenate.

For the purified enzyme experiment, the following levels of binding of clay minerals to enzymes were set to investigate 


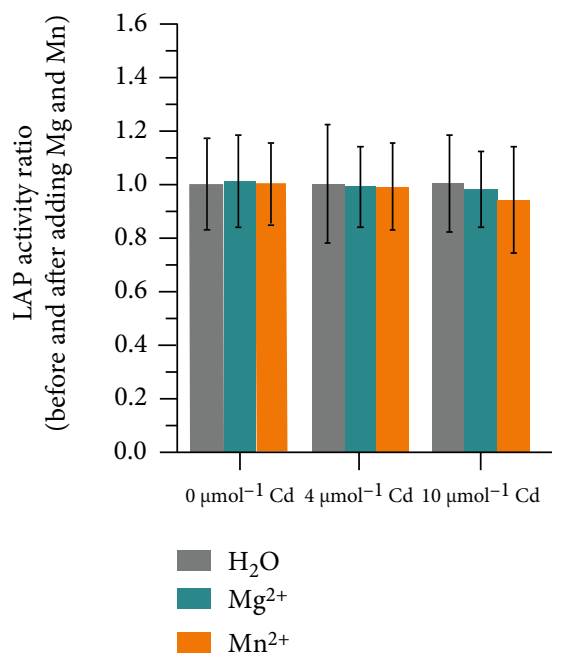

(a) Purified enzyme
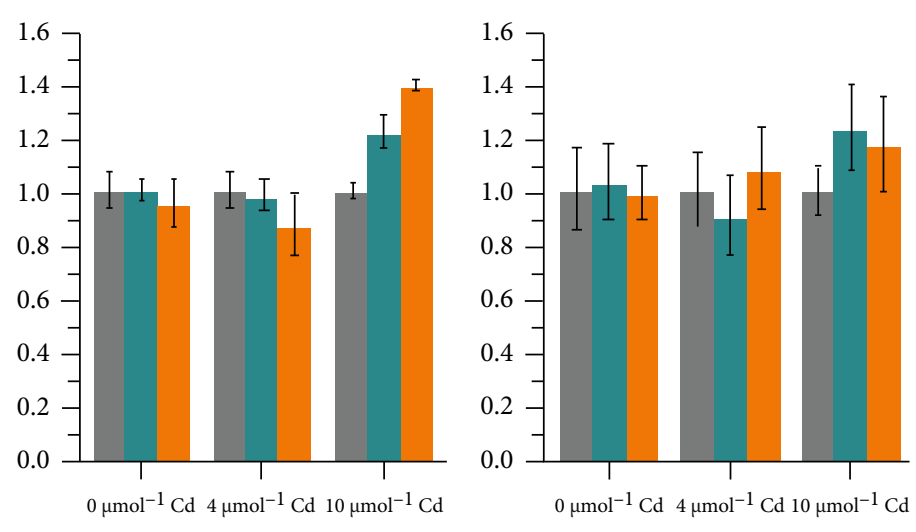

(b) Red soil (c) Purple soil

FIGURE 3: Proportion of change in the activity of Cd-contaminated LAP after the addition of Mg and Mn as restorative activators of LAP.

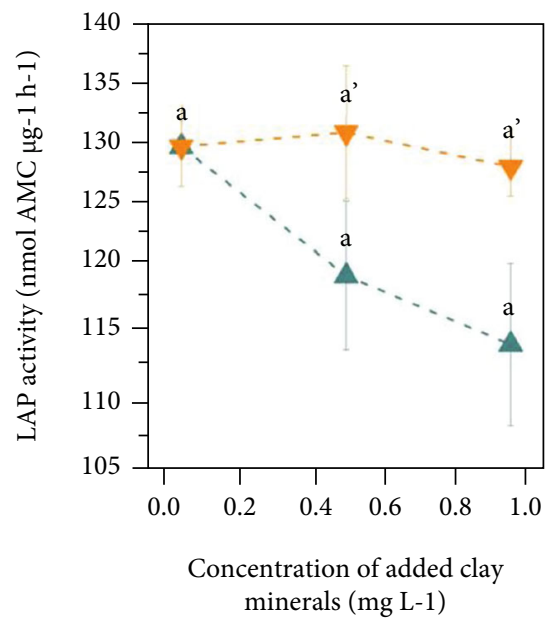

(a) Purified enzyme

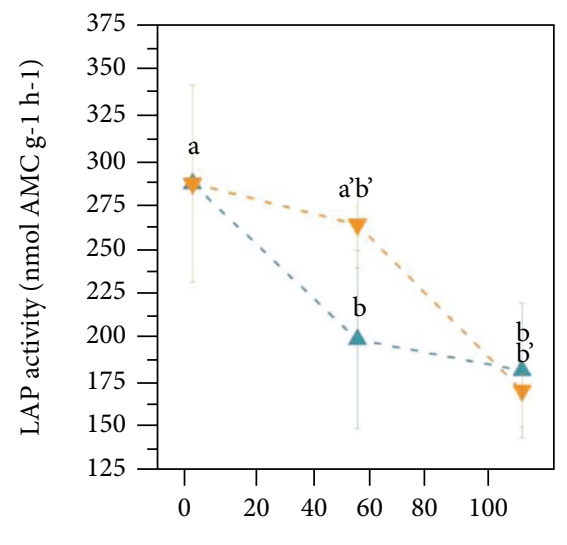

Addition of clay minerals (mg g-1 soil)

(b) Red soil

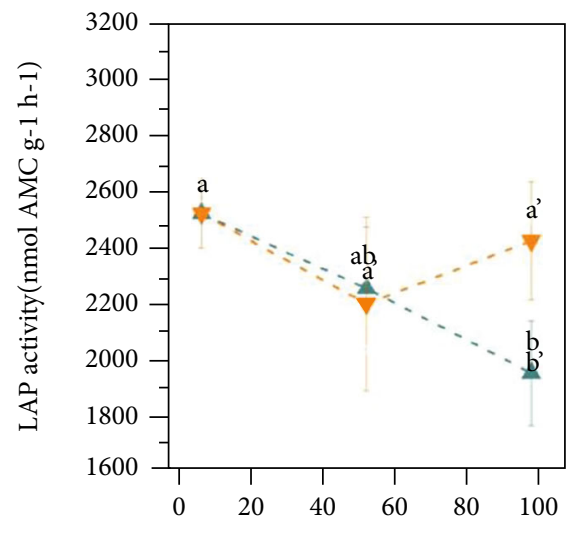

Addition of clay minerals (mg g-1 soil)

$$
\begin{aligned}
& -\boldsymbol{-} \text { - Montmorillonite } \\
& -\boldsymbol{\nabla}-\text { Kaolinite }
\end{aligned}
$$

(c) Purple soil

FIGURE 4: Effect of adding different amounts of montmorillonite and kaolinite on LAP activity in purified LAP, LAP in red soil, and LAP in purple soil.

the effect of clay minerals on Cd: (1) free enzyme: no clay minerals added; (2) adsorbed enzyme: clay minerals added during incubation to make the LAP working solution containing final concentrations of $0.5 \mathrm{mg} \mathrm{L}^{-1}$ and $1 \mathrm{mg} \mathrm{L}^{-1}$ clay minerals, respectively; and (3) immobilized enzyme: clay mineral-immobilized LAP was made in advance.

2.3.3. Cd Toxicity on LAP. To determine the Cd toxicity to LAP, after adding homogenate or LAP work solution to 96-well plates, $50 \mu \mathrm{L}$ of different concentrations of Cd solution $\left(\mathrm{CdCl}_{2}\right)$ was added and contaminated LAP for 30 minutes at $25^{\circ} \mathrm{C}$.

Inhibition of LAP by Cd was calculated for soil LAP and purified LAP activity at final Cd concentrations of $0,10,20$,
$50,100,200,500$, and $1000 \mu \mathrm{mol} \mathrm{L}^{-1}$ to quantify the toxicity of Cd on LAP.

Changes in kinetic constants $\left(V_{\max }\right.$ and $\left.K_{m}\right)$ of soil LAP and purified LAP were compared at final Cd concentrations of 0,4 , and $10 \mu \mathrm{mol} \mathrm{L}^{-1}$ to infer the type of inhibition of LAP by $\mathrm{Cd}$. The enzyme activities of soil LAP and purified LAP were determined at different concentrations of substrate (final concentrations of $0,10,20,40,100,200,300$, and $400 \mu \mathrm{mol} \mathrm{L}^{-1}$, respectively), and $V_{\max }$ and $K_{m}$ were calculated using the Michaelis-Menten equation.

In order to have a more insightful understanding of the inhibitory effect of Cd on LAP, we chose argentum (Ag) and hydrargyrum $(\mathrm{Hg})$, which are both inhibitory metals to hydrolase like $\mathrm{Cd}$, as a reference to observe the inhibitory 


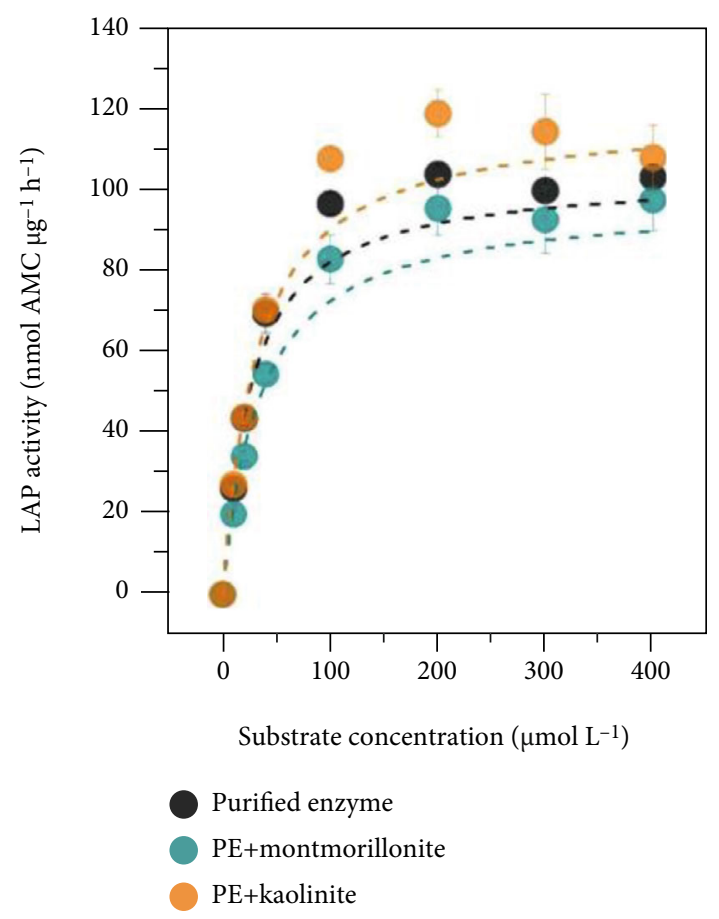

(a) Purified enzyme

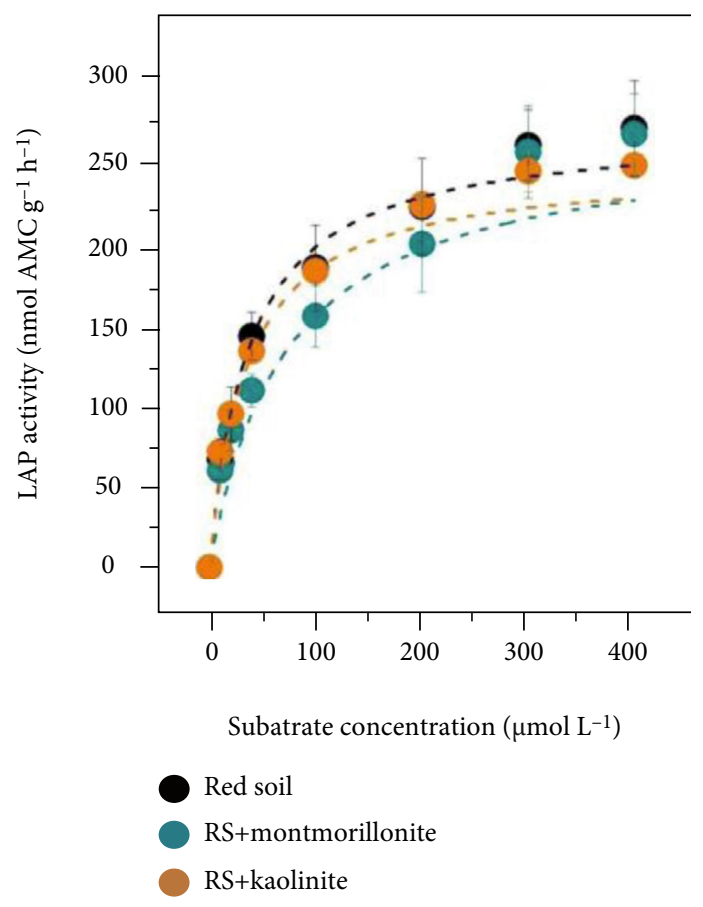

(b) Red soil

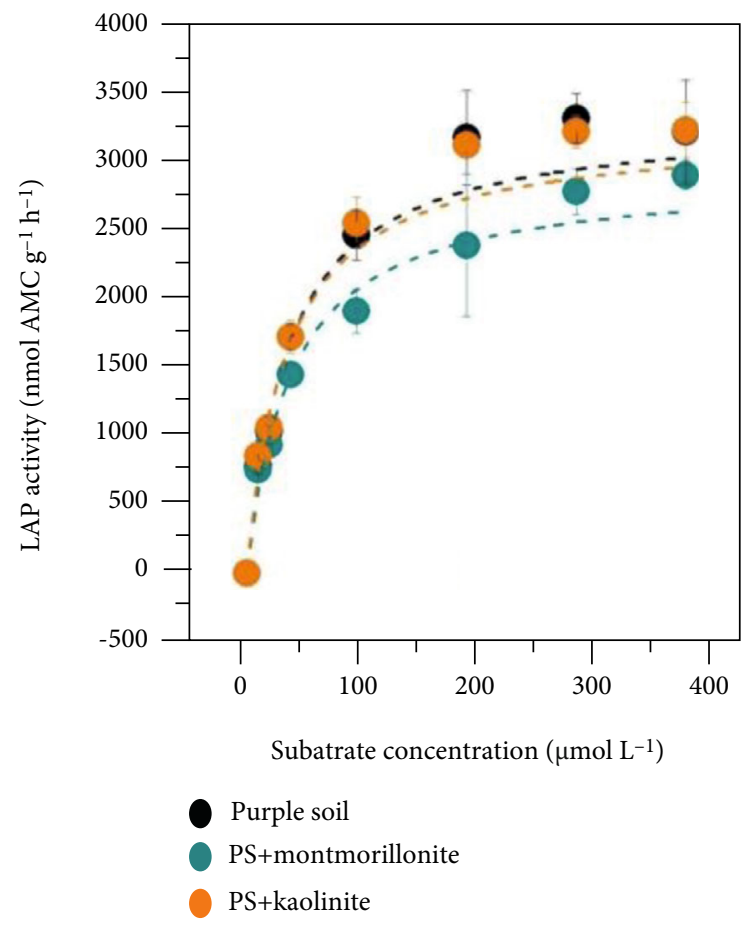

(c) Purple soil

FIGURE 5: Effect of adding different amounts of montmorillonite and kaolinite on the kinetic curve of LAP in purified LAP, LAP in red soil, and LAP in purple soil.

effect and type of LAP inhibition by different inhibitory metals. We also chose cobalt (Co) and boron (B), which are accelerators of hydrolase, and magnesium $(\mathrm{Mg})$ and manganese $(\mathrm{Mn})$, metals that can occupy and substitute metal ions at two exchangeable sites in LAP to affect $K_{m}$, to observe the effect of different metals on LAP activity under the same conditions [33-38].

Additionally, the recovery of Cd-contaminated LAP activity by the addition of $\mathrm{Mg}$ and $\mathrm{Mn}$ was used to infer the mechanism of Cd inhibition of LAP [37]. In the recovery 
TABLE 2: Changes in the kinetic constants $\left(V_{\max }\right.$ and $K_{m}$ ) of LAP by montmorillonite and kaolinite.

\begin{tabular}{|c|c|c|c|c|c|c|c|c|c|}
\hline & \multicolumn{3}{|c|}{ Purified LAP } & \multicolumn{3}{|c|}{ Red soil } & \multicolumn{3}{|c|}{ Purple soil } \\
\hline & $\mathrm{PE}$ & $\mathrm{PE}+\mathrm{M}$ & $\mathrm{PE}+\mathrm{K}$ & RS & $\mathrm{RS}+\mathrm{M}$ & $\mathrm{RS}+\mathrm{K}$ & PS & PS+M & $\mathrm{PS}+\mathrm{K}$ \\
\hline$V_{\max }$ & $104.05^{\mathrm{A}}$ & $97.73^{\mathrm{A}}$ & $119.1^{\mathrm{A}}$ & $257.18^{\mathrm{A}^{\prime}}$ & $253.65^{\mathrm{A}^{\prime}}$ & $235.26^{\mathrm{A} \prime}$ & $3312.61^{\mathrm{B} / 1}$ & $2898.44^{\mathrm{A} / \prime}$ & $3226.65^{\mathrm{B} / \prime}$ \\
\hline$K_{m}$ & $26.42^{\mathrm{a}}$ & $34.34^{\mathrm{b}}$ & $31.74^{\mathrm{ab}}$ & $36.92^{\mathrm{a}^{\prime}}$ & $72.02^{\mathrm{b} /}$ & $35.09^{\mathrm{a} \prime}$ & $38.13^{\mathrm{a} / \prime}$ & $40.44^{\mathrm{a} / \prime}$ & $36.79^{\mathrm{a} / \prime}$ \\
\hline$R^{2}$ & 0.99 & 0.99 & 0.97 & 0.99 & 0.96 & 0.99 & 0.99 & 0.98 & 0.99 \\
\hline
\end{tabular}

PE means purified enzyme (LAP), RS means red soil, PS means purple soil, and $+\mathrm{M}$ or $+\mathrm{K}$ means adding montmorillonite or kaolinite.

experiment, after measuring the LAP activity inhibited by $\mathrm{Cd}, \mathrm{Mg}$ and $\mathrm{Mn}$ solutions at a final concentration of $4 \mu \mathrm{mol} \mathrm{L}{ }^{-1}$ were added to observe the change in LAP activity.

\subsection{Data Analysis}

2.4.1. Enzyme Activity. Soil LAP activity was expressed in units of nmol AMC $\cdot \mathrm{g}^{-1} \cdot \mathrm{h}^{-1}$ and calculated by the following equations which were modified from Deforest [31] and Wang et al. [32]:

$$
\begin{aligned}
& \operatorname{Activity}\left(\mathrm{nmol} \mathrm{AMC} \times \mathrm{g}^{-1} \times \mathrm{h}^{-1}\right) \\
& =\frac{\text { Net fluorescence } \times V(\mathrm{~mL})}{\text { Emission coefficient } \times v(\mathrm{~mL}) \times T(\mathrm{~h}) \times \mathrm{DM}(\mathrm{g})},
\end{aligned}
$$

where Net fluorescence is the actual fluorescence value of AMC produced by the enzymatic reaction of LAP in soil, which can be calculated by equation (2); $V$ is the total volume of homogenate, $120 \mathrm{~mL}$ for this experiment; the Emission coefficient indicates the fluorescence value per unit AMC (nmol), which can be calculated by equation (4); $v$ is the volume of homogenate in a single incubation well, $0.1 \mathrm{~mL}$ for this experiment; $T$ is incubation time, $1 \mathrm{~h}$ for purple soil and purified LAP, $3 \mathrm{~h}$ for red soil; DM is the dry soil mass corresponding to $0.5 \mathrm{~g}$ of fresh soil.

$$
\text { Net fluorescence }=\frac{f_{\text {sample assay }}}{\text { Quench coefficient }}-f_{\text {substrate control }}
$$

where $f$ is the fluorescence value measured by the marked well; the Quench coefficient indicates the effect of soil on the fluorescence values of AMC, which can be calculated by

$$
\text { Quench coefficient }=\frac{f_{\text {quench }}}{f_{\text {standard }}},
$$

$$
\text { Emission coefficient }\left(\text { fluorescence } \mathrm{nmol}^{-1}\right)=\frac{f_{\text {standard }}}{0.5 \mathrm{nmol}} \text {. }
$$

Purified LAP activity was expressed in units of nmol $\mathrm{AMC} \cdot \mu \mathrm{g}^{-1} \cdot \mathrm{h}^{-1}$ :

$$
\begin{aligned}
& \operatorname{Activity}\left(\mathrm{nmol} \text { AMC } \times \mu \mathrm{g}^{-1} \times \mathrm{h}^{-1}\right) \\
& =\frac{\text { Net fluorescence }}{\text { Emission coefficient } \times T(\mathrm{~h}) \times \operatorname{enzyme}(\mu \mathrm{g})},
\end{aligned}
$$

Net fluorescence

$$
=f_{\text {sample assay }}-f_{\text {substrate control }} \text {. }
$$

2.4.2. Inhibition Ratio and Type of Inhibition. Variation of the maximum rate of reaction $\left(V_{\max }\right)$ and the Michaelis constant $\left(K_{m}\right)$ could deduce the type of inhibition of enzymatic reactions by inhibitors [35].

To better describe and compare the inhibition of LAP by different inhibitors (Cd, clay minerals, and other ion), the inhibition ratio was expressed by following equations from Acosta-Martínez [39]:

$$
\begin{aligned}
\text { Inhibition ratio }(\%)= & \frac{\left(\text { Activity }_{\text {control }}-\text { Activity }_{\text {treatment }}\right)}{\text { Activity }_{\text {control }}} \% . \\
& \times 100
\end{aligned}
$$

The type of inhibition of LAP by the inhibitor can be known from the change in kinetic constants $K_{m}$ and $V_{\max }$, which can be calculated according to the Michaelis-Menten equation (7) and the Lineweaver-Burk double-reciprocal equation (8) $[40,41]$ :

$$
v=\frac{V_{\max }[S]}{K_{m}+[S]},
$$

where $v$ is the initial reaction rate at the substrate concentration $[S] ; V_{\max }$ is the maximum rate of reaction and $K_{m}$ is the Michaelis constant.

$$
\frac{1}{v}=\frac{K_{m}}{V_{\max }} \cdot \frac{1}{[S]}+\frac{1}{V_{\max }} .
$$

2.4.3. Statistical Analysis. Differences between treatments were analyzed by one-way ANOVA following the Bonferroni post hoc test in SPSS Statistics 24 (IBM SPSS, Somers, NY, USA). Values of $P<0.05$ were considered to be significant. Data are expressed as mean \pm standard error (number 


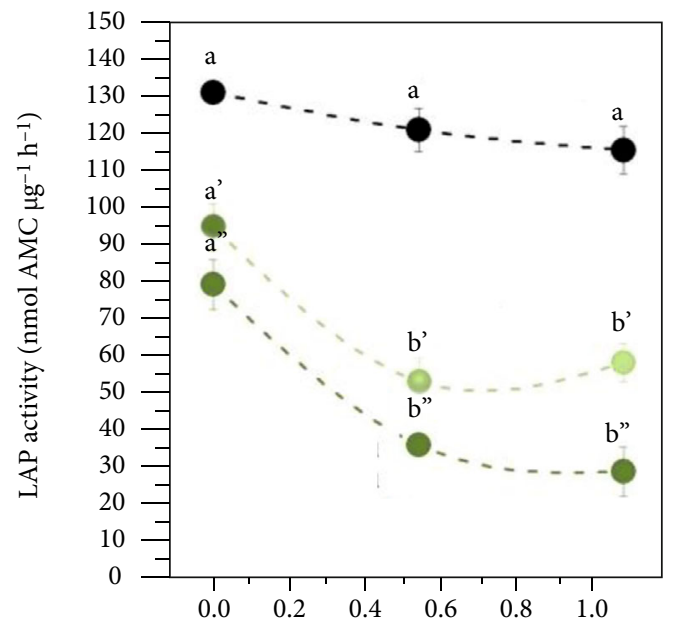

Concentration of addes clay minerals $\left(\mathrm{mg} \mathrm{L}^{-1}\right)$

- $0 \mu \mathrm{mol} \mathrm{L}-1 \mathrm{Cd}$

$4 \mu \mathrm{mol} \mathrm{L}-1 \mathrm{Cd}$

- $10 \mu \mathrm{mol} \mathrm{L}-1 \mathrm{Cd}$

(a) Montmorillonite-purified enzyme

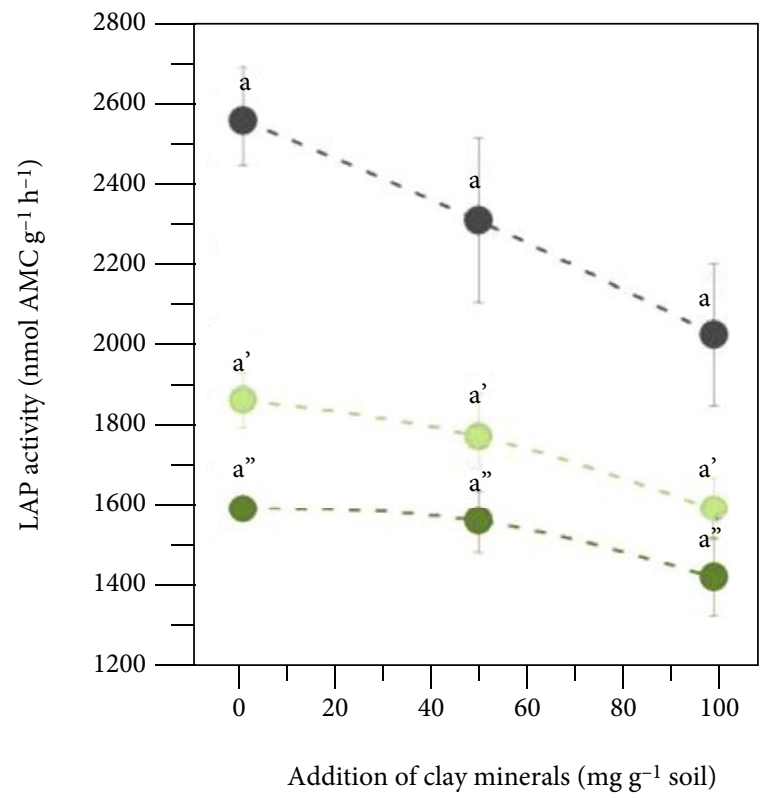

(c) Montmorillonite-purple soil

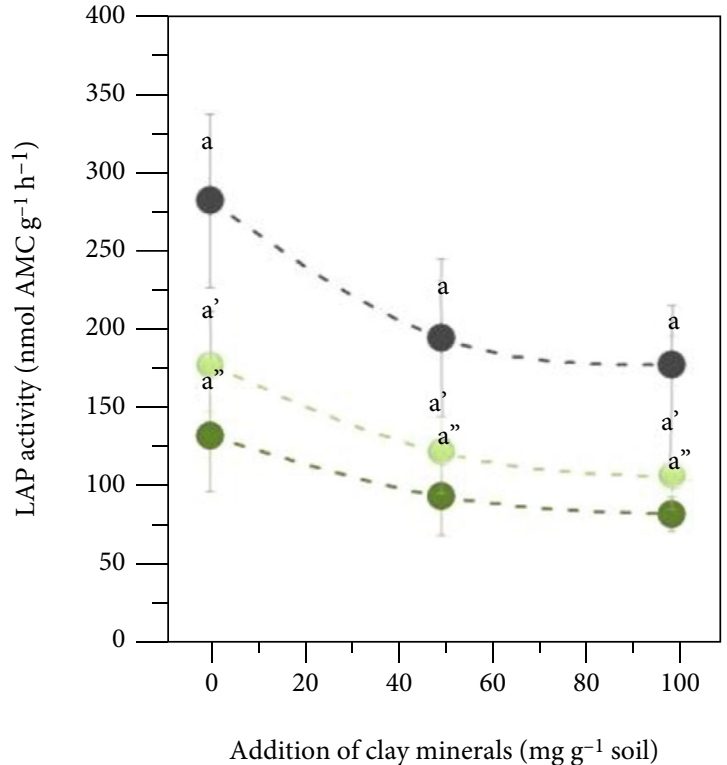

(b) Montmorillonite-red soil

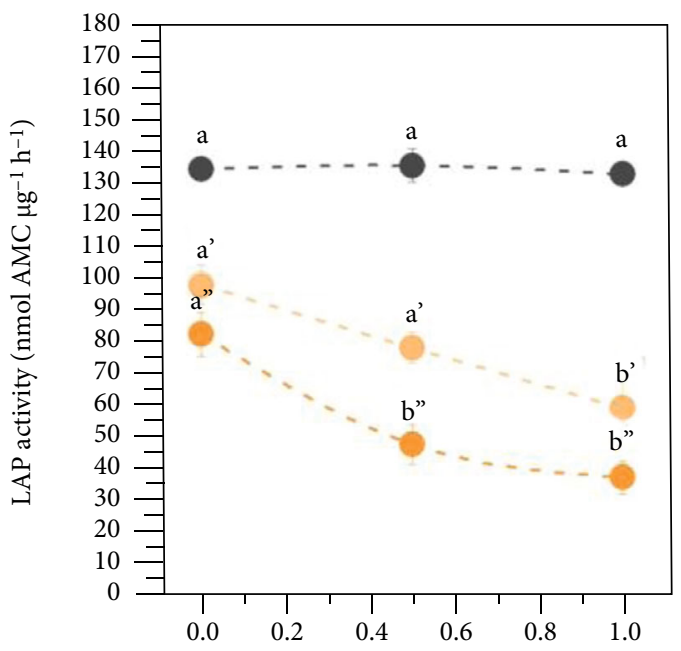

Concentration of added clay minerals $\left(\mathrm{mg} \mathrm{L}^{-1}\right)$

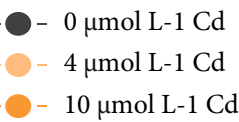

(d) Kaolinite-purified enzyme

FIgURE 6: Continued. 


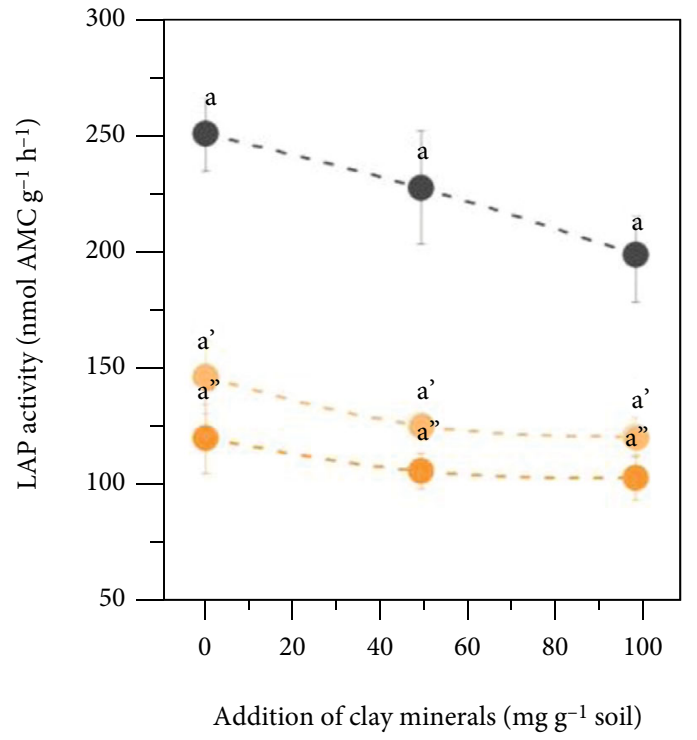

(e) Kaolinite-red soil

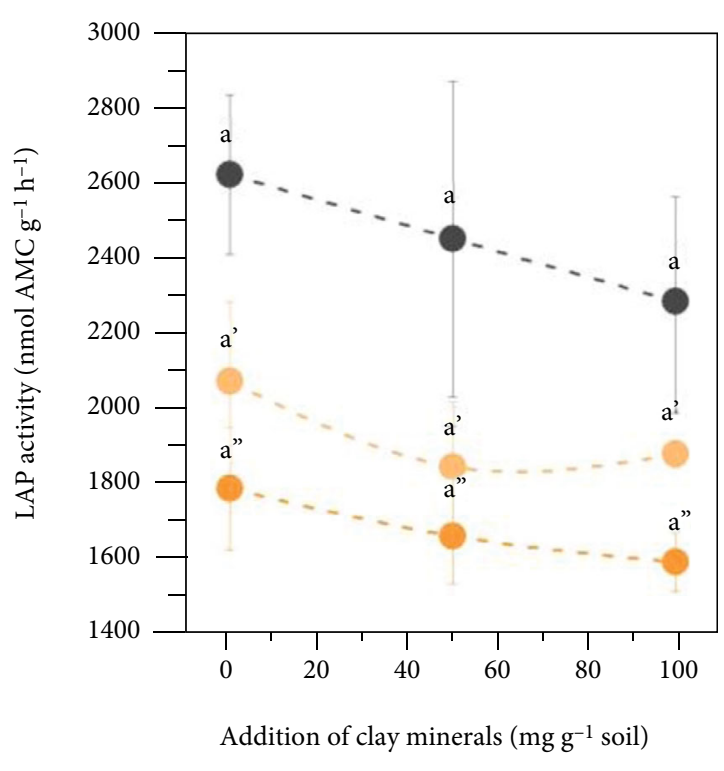

(f) Kaolinite-purple soil

FIGURE 6: Effect of montmorillonite and kaolinite on the activity of purified LAP, LAP in red soil, and LAP in purple soil in the presence of 0 , 4 , and $10 \mu \mathrm{mol} \mathrm{L}{ }^{-1} \mathrm{Cd}$.

of replicates $n \geq 3$ ), with different letters indicating significant differences. The dependences of enzyme activity with substrate concentration were represented with the MichaelisMenten equations. The fitting and calculation of kinetic constants were performed using a nonlinear fitting equation (Growth/Sigmoidal Hill) in OriginPro 9.1 (OriginLab Corp., Northampton, MA, USA).

\section{Results and Discussion}

3.1. Effect of $C d$ and Other Ions on LAP. Cadmium inhibited both soil LAP and purified LAP. The inhibition ratio of Cd on LAP increased sharply with increasing Cd concentration in the range of $0-200 \mu \mathrm{mol} \mathrm{L}^{-1}$, and the inhibition ratio showed a logarithmic increase (Figure 1(a)). This is consistent with the findings that $\mathrm{Cd}$ is a strong inhibitor of LAP in both biochemical and soil studies [27, 41, 42]. When contaminated with low concentrations of $\mathrm{Cd}(\mathrm{Cd}$ concentration less than $10 \mu \mathrm{mol} \mathrm{L}^{-1}$ ), LAP in red soil was more sensitive to Cd than that in purple soil, while LAP in both soils responded equally to $\mathrm{Cd}$ contamination when $\mathrm{Cd}$ was greater than $10 \mu \mathrm{mol} \mathrm{L}^{-1}$ (Figures $1(\mathrm{a}), 1(\mathrm{c})$, and $1(\mathrm{~d})$ ). This indicates that the $\mathrm{pH}$ of soil may influence Cd toxicity when the $\mathrm{Cd}$ concentration is less than $10 \mu \mathrm{mol} \mathrm{L}^{-1}$. At low $\mathrm{Cd}$ concentrations, the effective Cd concentration in the soil also depends on the concentration of $\mathrm{Cd}$ being adsorbed. When soil $\mathrm{pH}$ is low, soil components such as clay minerals and organic matter are less able to sorb Cd and are less likely to produce $\mathrm{Cd}(\mathrm{OH})_{2}$ precipitation, so more $\mathrm{Cd}^{2+}$ is free in the soil solution; therefore, Cd toxicity is likely to be greater $[43,44]$. In contrast, at higher Cd concentrations, soil properties, including $\mathrm{pH}$ (Table S1), did not affect Cd toxicity to soil LAP. The weaker inhibition of Cd on soil LAP than on purified LAP may be due to the adsorption of $\mathrm{Cd}$ by sorbent substances in soil homogenate, resulting in a lower effective concentration of $\mathrm{Cd}[45,46]$. Another explanation may be that certain components of the soil form a protective effect on LAP, resulting in a reduction in the toxicity of Cd to LAP [47].

Enzyme kinetic analysis indicated that $\mathrm{Cd}$ may be a noncompetitive inhibitor of both purified LAP and soil LAP (Figures 1(b)-1(d)). After the addition of 4 and $10 \mu \mathrm{mol} \mathrm{L}^{-1}$ of Cd, $V_{\text {max }}$ for the enzymatic reaction of soil LAP and purified LAP decreased, while no significant difference was observed in $K_{m}$ (Table 1). This indicates that the addition of Cd only reduced the effective amount of the enzyme without reducing the affinity between the enzyme and the substrate. It can be inferred that $\mathrm{Cd}$ disrupts the conformation on LAP and thus renders some LAP inactive $[26,27]$.

The inhibitory effect of Cd on LAP activity was comparable $\mathrm{Ag}$ and $\mathrm{Hg}$ but stronger than that of $\mathrm{Co}, \mathrm{B}, \mathrm{Mg}$, and $\mathrm{Mn}$ (Figures S2-S4). Generally, the effect of $\mathrm{Ag}$ on soil LAP and purified LAP was similar to that of Cd. Soil LAP and purified LAP activities were strongly inhibited by Ag. The inhibitory effect of $\mathrm{Hg}$ on LAP at the same concentration was slightly greater than that of $\mathrm{Cd}$. Accelerator metal Co promoted soil LAP and purified LAP activities at low concentrations and inhibited them at high concentrations. The inflection points for purified LAP and LAP in red soil were 250 and $200 \mu \mathrm{mol} \mathrm{L}^{-1}$, respectively. B, $\mathrm{Mg}$, and $\mathrm{Mn}$ had little effect on LAP activities. The purified enzyme responded most strongly to their inhibition, relative to the two soil LAP contaminated by $\mathrm{Cd} ; \mathrm{Ag}$ and $\mathrm{Hg}$ had a noncompetitive inhibition on both LAP in purple soil and purified LAP (Figure 2, Tables S3S5). Nevertheless, we also observed competitive inhibition 


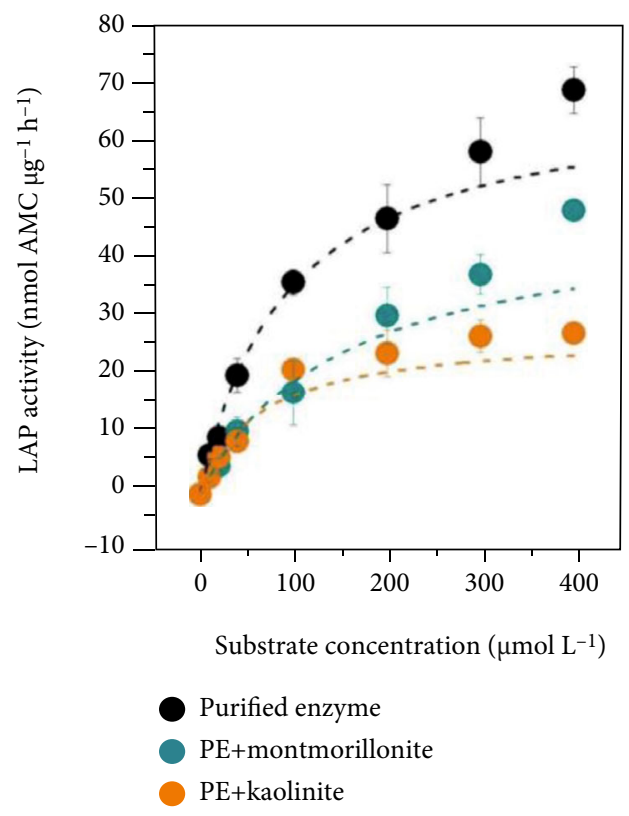

(a) Purified enzyme

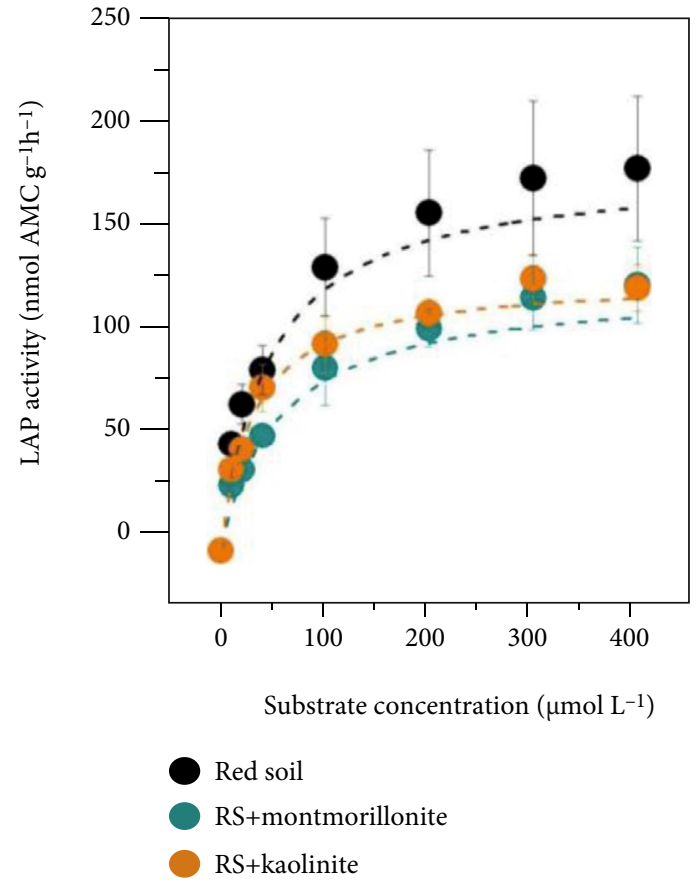

(b) Red soil

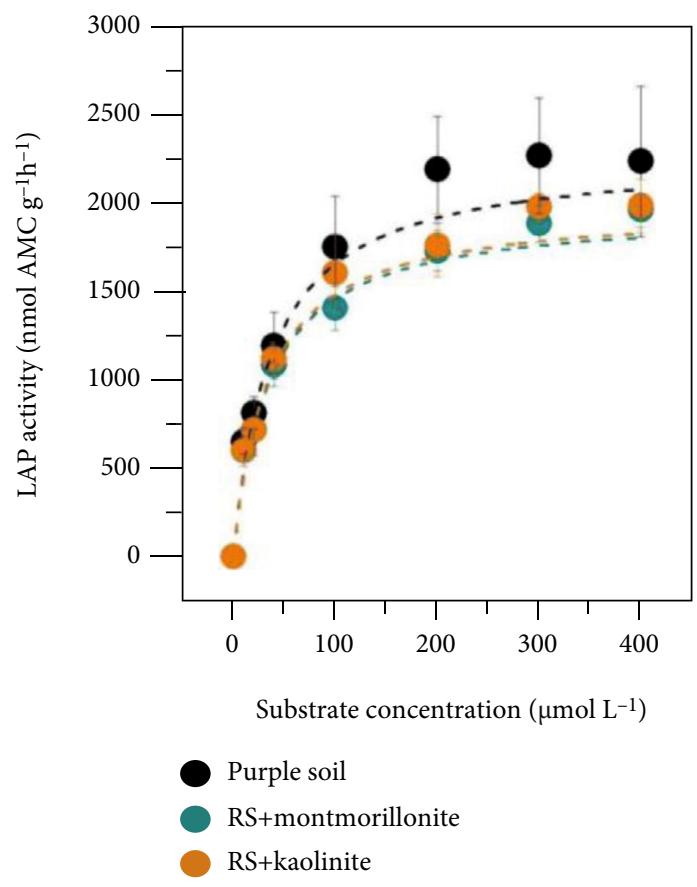

(c) Purple soil

FIGURE 7: Effect of montmorillonite and kaolinite on the kinetic curves of purified LAP, LAP in red soil, and LAP in purple soil in the presence of $10 \mu \mathrm{mol} \mathrm{L}^{-1} \mathrm{Cd}$.

of $\mathrm{Hg}$ on LAP in the red soil, indicating that other isozyme may exist in the red soil compared with the purified LAP and LAP in the purple soil.

The addition of $\mathrm{Mg}$ and $\mathrm{Mn}$, which are metals in the active site of LAP $[5,6]$, cannot restore the activity of purified LAP contaminated by $\mathrm{Cd}$, and the addition of $\mathrm{Mg}$ and Mn only slightly changed the activity of LAP in red soil and purple soil (Figure 3). This suggests that $\mathrm{Mg}$ and $\mathrm{Mn}$ cannot effectively restore the activity of LAP by competing with $\mathrm{Cd}$ for the divalent metal sites on LAP.

3.2. Effect of Clay Minerals on LAP. Clay minerals showed different effects on LAP activity (Figure 4 ). The addition of clay minerals does not significantly affect the activity of purified LAP (Figure 4(a)). In the soil system (Figures 4(b) and $4(c))$, the addition of montmorillonite significantly reduced 
TABLE 3: Changes in the kinetic constants $\left(V_{\max }\right.$ and $\left.K_{m}\right)$ of LAP by montmorillonite and kaolinite with $10 \mu \mathrm{mol} \mathrm{L} \mathrm{L}^{-1} \mathrm{Cd}$ contamination.

\begin{tabular}{|c|c|c|c|c|c|c|c|c|c|}
\hline & \multicolumn{3}{|c|}{ Purified enzyme } & \multicolumn{3}{|c|}{ Red soil } & \multicolumn{3}{|c|}{ Purple soil } \\
\hline & $\mathrm{PE}$ & $\mathrm{PE}+\mathrm{M}$ & $\mathrm{PE}+\mathrm{K}$ & RS & $\mathrm{RS}+\mathrm{M}$ & $\mathrm{RS}+\mathrm{K}$ & PS & $\mathrm{PS}+\mathrm{M}$ & $\mathrm{PS}+\mathrm{K}$ \\
\hline$V_{\text {max }}$ & $69.11^{\mathrm{C}}$ & $48.59^{\mathrm{B}}$ & $27.63^{\mathrm{A}}$ & $179.00^{\mathrm{B} /}$ & $124.42^{\mathrm{A} \prime}$ & $127.37^{\mathrm{A} \prime}$ & $2273.60^{\mathrm{B} / 1}$ & $1964.32^{\mathrm{A} / \prime}$ & $1988.37^{\mathrm{B} / \prime}$ \\
\hline$K_{m}$ & $93.22^{\mathrm{b}}$ & $152.1^{\mathrm{b}}$ & $63.5^{\mathrm{a}}$ & $46.18^{\mathrm{b} /}$ & $55.91^{\mathrm{c} \prime}$ & $31.23^{\mathrm{a} \prime}$ & $36.74^{\mathrm{a} / \prime}$ & $34.13^{\mathrm{a} / \prime}$ & $33.68^{\mathrm{a} \prime \prime}$ \\
\hline$R^{2}$ & 0.99 & 0.99 & 0.98 & 0.99 & 0.99 & 0.99 & 0.99 & 0.99 & 0.99 \\
\hline
\end{tabular}

PE means purified enzyme (LAP), RS means red soil, PS means purple soil, and $+\mathrm{M}$ or $+\mathrm{K}$ means adding montmorillonite or kaolinite.

the LAP activity in red soil and purple soil $(P<0.05)$. The greater the amount of montmorillonite added, the lower the enzyme activity. When the amount of montmorillonite was 50 and $100 \mathrm{mg} \mathrm{g}^{-1}$ soil, the inhibition rate of LAP in red soil was $30.96 \%$ and $36.42 \%$ and was $10.77 \%$ and $22.78 \%$ in purple soil. The addition of kaolinite had no significant effect on LAP activity. The different effects of the two clay minerals may be attributed to the fact that montmorillonite in the $2: 1$ layer has a higher specific surface area and adsorption capacity than kaolinite in the 1:1 layer-type structure (Figure S1 and Table S2). Thus, montmorillonite can mask some of the active sites by adsorption on LAP, resulting in a decrease in LAP activity [22].

Different lowercase letters $a$ and $b$ indicate significant differences in LAP activities caused by montmorillonite, and $\mathrm{a}^{\prime}$ and $\mathrm{b}^{\prime}$ indicate kaolinite.

Figure 5 shows the effect of adding clay minerals on the kinetics of soil LAP and purified LAP. The addition of low concentrations of montmorillonite and kaolinite $\left(0.5 \mathrm{mg} \mathrm{L}^{-1}\right.$ for purified LAP and $50 \mathrm{mgg}^{-1}$ soil for soil LAP) resulted in a decreasing trend in $V_{\max }$ values for both soil LAP and purified LAP, with only the addition of montmorillonite to the purple clay producing a significant decrease in $V_{\max }$ (Table 2). When the substrate concentration was relatively low (concentration less than $200 \mu \mathrm{mol} \mathrm{L}^{-1}$ ), the enzyme activity decreased significantly after clay mineral addition (Figure 4), and the addition of both montmorillonite and kaolinite changed the $K_{m}$ value of the purified enzyme (Table 2), indicating that the affinity of LAP and substrates decreased in the presence of clay minerals. Clay minerals reduce enzyme activity because the adsorption of the mineral to the enzyme changes the conformational structure of the protein, ultimately altering its catalytic properties and reducing its activity and $V_{\max }$ [48].

Clay minerals still had an effect on LAP activity with Cd contamination (Figure 6). Adding montmorillonite or kaolinite will cause a decrease in LAP activity, but there is no statistically significant difference in this decreasing trend, and in general, the greater the amount of clay mineral added, the greater the reduction in enzyme activity $[49,50]$. This suggests that the presence or absence of $\mathrm{Cd}$ had no effect on the ability of the clay minerals to reduce enzyme activity (Figures 4 and 6). According to Figures 6(a) and 6(d), the addition of clay minerals had almost no effect on the enzymatic activity of purified LAP $\left(0 \mu \mathrm{mol} \mathrm{L}^{-1} \mathrm{Cd}\right)$; in the presence of $\mathrm{Cd}$ contamination with concentrations of $4 \mu \mathrm{mol} \mathrm{L}^{-1}$ and $10 \mu \mathrm{mol} \mathrm{L}^{-1}$, the inhibition rate of Cd on LAP increases significantly with the addition of clay minerals.
In contrast, the inhibitory effect of Cd on LAP in red and purple soil did not increase significantly with the addition of clay minerals. The reason might be that soil enzymes are in different environments than the purified enzyme. There are only buffer, substrate, metal solution, and enzyme in the purified enzyme incubation systems. Thus, this system can be regarded as a homogeneous liquid wherein the metal ions and enzyme could diffuse easily. Clay minerals may adsorb and concentrate the enzyme and $\mathrm{Cd}$ ions from the dispersion system on their surface, which increases the chance of Cd-enzyme interaction and the inhibitive effect of $\mathrm{Cd}$ on LAP.

Lowercase letters $\mathrm{a}$ and $\mathrm{b}$ indicate significant differences in LAP activities caused by $0 \mu \mathrm{mol} \mathrm{L}^{-1} \mathrm{Cd}$, and $\mathrm{a}^{\prime}$ and $\mathrm{b}^{\prime}$ or $a^{\prime \prime}$ and $b^{\prime \prime}$ indicate significant differences in LAP activities caused by 4 and $10 \mu \mathrm{mol} \mathrm{L}^{-1} \mathrm{Cd}$, respectively.

According to Tables 1 and 2, the addition of clay minerals decreased the enzyme activity and $V_{\max }$ of LAP, and the kinetic constants of LAP were affected by both clay minerals and $\mathrm{Cd}$. The decrease in $V_{\max }$ of the purified enzyme was mainly caused by $\mathrm{Cd}$, but when $\mathrm{Cd}$ and clay minerals were present together, the clay minerals exacerbated the inhibitory effect of $\mathrm{Cd}$, and the effect of kaolinite was stronger than that of montmorillonite (Figure 7 and Table 3 ). $K_{m}$ in purple soil was not affected by the addition of $\mathrm{Cd}$ or clay minerals, but, in both the purified enzyme and in the red soil, it was concluded that montmorillonite decreased the affinity of LAP to the substrate and kaolinite increased the affinity of LAP to the substrate. It can be concluded that the presence of both $\mathrm{Cd}$ and clay minerals in the purified enzyme system amplifies the inhibitory effect of $\mathrm{Cd}$ on LAP, possibly due to the ability of clay minerals to adsorb LAP and Cd [51]. The reason for the different results observed in the two soils is that the type and content of clay minerals differ between the red and purple soils, and these differences make a difference in the effect of Cd on LAP contamination [47].

3.3. Effect of $C d$ on Immobilized LAP. As shown in Figure 8 and Table 4, the montmorillonite-immobilized enzyme showed a nonsignificant decreasing trend in $V_{\max }$ with increasing $\mathrm{Cd}$ concentration under the influence of 0,4 , and $10 \mu \mathrm{mol} \mathrm{L}^{-1} \mathrm{Cd}$, while the kaolinite-immobilized enzyme did not differ significantly under the three concentrations of Cd contamination. No significant change in $K_{m}$ was observed for the enzymes immobilized by the two clay minerals. Comparison with the kinetic constants of the purified LAP (free enzyme) in Figure 1(b) and Table 1 shows that 


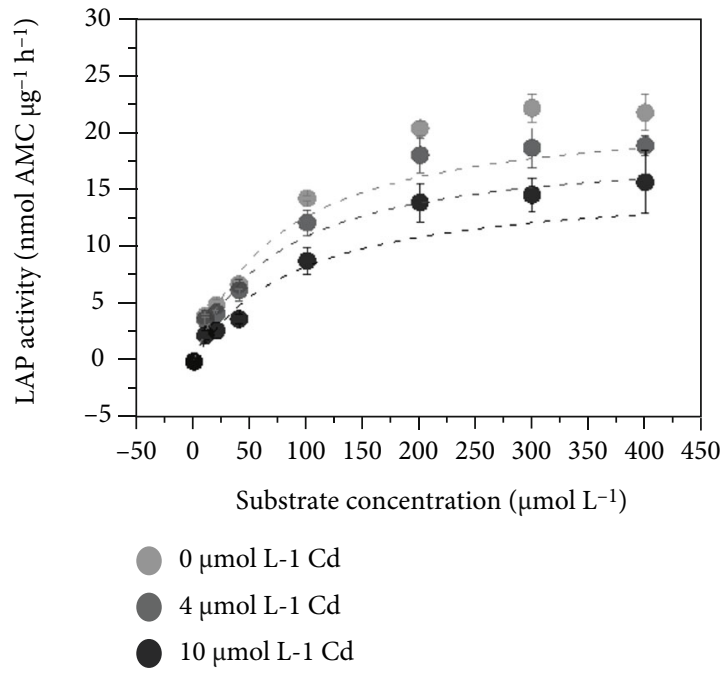

(a) Montmorillonite immobilized LAP

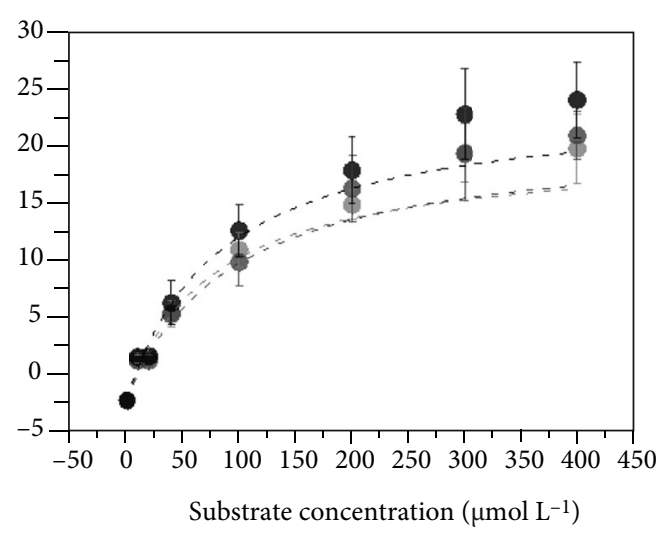

(b) Kaolinite immobilized LAP.

FIGURE 8: Effect of Cd on the kinetics curves of montmorillonite-immobilized LAP and kaolinite-immobilized LAP.

TABLE 4: Changes in the kinetic constants $\left(V_{\max }\right.$ and $\left.K_{m}\right)$ of montmorillonite-immobilized LAP and kaolinite-immobilized LAP with 0, 4, and $10 \mu \mathrm{mol} \mathrm{L}{ }^{-1} \mathrm{Cd}$ contamination.

\begin{tabular}{|c|c|c|c|c|c|c|}
\hline & \multicolumn{3}{|c|}{ Montmorillonite-immobilized enzyme } & \multicolumn{3}{|c|}{ Kaolinite-immobilized enzyme } \\
\hline & $0 \mu \mathrm{mol} \mathrm{L}-1 \mathrm{Cd}$ & $4 \mu \mathrm{mol} \mathrm{L}{ }^{-1} \mathrm{Cd}$ & $10 \mu \mathrm{mol} \mathrm{L}{ }^{-1} \mathrm{Cd}$ & $0 \mu \mathrm{mol} \mathrm{L}{ }^{-1} \mathrm{Cd}$ & $4 \mu \mathrm{mol} \mathrm{L}-1 \mathrm{Cd}$ & $10 \mu \mathrm{mol} \mathrm{L}{ }^{-1} \mathrm{Cd}$ \\
\hline$V_{\max }$ & $22.19^{\mathrm{A}}$ & $18.93^{\mathrm{A}}$ & $15.73^{\mathrm{A}}$ & $20.52^{\mathrm{A} \prime}$ & $21.60^{\mathrm{A} \prime}$ & $24.49^{\mathrm{A} \prime}$ \\
\hline$K_{m}$ & $74.42^{\mathrm{a}}$ & $72.44^{\mathrm{a}}$ & $88.65^{\mathrm{a}}$ & $76.53^{a^{\prime}}$ & $93.19^{a \prime}$ & $83.68^{\mathrm{a}^{\prime}}$ \\
\hline$R^{2}$ & 0.98 & 0.98 & 0.99 & 0.99 & 0.99 & 0.99 \\
\hline
\end{tabular}

the significant increase in $K_{m}$ of the immobilized enzyme suggests that the presence of clay minerals reduces the affinity between the enzyme and the substrate. When the free LAP was contaminated with $10 \mu \mathrm{mol} \mathrm{L}^{-1}$ of $\mathrm{Cd}, V_{\max }$ of the free LAP decreased to $63.29 \%$ and $K_{m}$ became $161.19 \%$ of that of the uncontaminated enzyme, respectively. In contrast, $V_{\max }$ of montmorillonite-immobilized enzyme and kaolinite-immobilized enzyme changed to $70.89 \%$ and $119.35 \%$ of those when they were not contaminated, respectively, and $K_{m}$ changed to $119.12 \%$ and $109.34 \%$, respectively. This indicates that the immobilized enzymes showed less change in $V_{\max }$ and $K_{m}$ when contaminated with $\mathrm{Cd}$, and therefore, the clay mineral-immobilized LAPs were more resistant to Cd contamination [49, 51-53].

The difference in the immobilized enzyme and free enzyme can also explain the difference in the response of soil LAP and purified LAP to Cd contamination. Clay mineralimmobilized enzymes are more resistant to $\mathrm{Cd}$ toxicity than free enzymes, so the same concentration of $\mathrm{Cd}$ inhibits the clay mineral-immobilized enzyme less than the free enzyme, which is why the inhibition ratio of soil enzymes under the same concentration of $\mathrm{Cd}$ is lower than that of purified enzyme. Since soil enzymes are a mixture of free and immobilized enzymes, the sensitivity of soil enzymes to $\mathrm{Cd}$ contamination should be somewhere between free and immobilized enzymes, and therefore, the inhibition rate of soil enzymes is usually lower than that of purified enzymes (free enzymes) when faced with the same concentration of Cd contamination.

\section{Conclusion}

The inhibitory effect of Cd on LAP increased logarithmically with the increasing $\mathrm{Cd}$ concentration, and $\mathrm{Cd}$ produced noncompetitive inhibition on both soil LAP and purified LAP. Cd inhibited the enzymatic reaction by disrupting the conformation of the enzyme protein, which cannot be restored by adding the metals associated with the LAP active site. Regardless of the presence of $\mathrm{Cd}$, the addition of clay minerals will generally reduce the activity and maximum reaction rate $\left(V_{\max }\right)$ of LAP, and the effect of montmorillonite is stronger than that of kaolinite. Montmorillonite decreases the affinity between LAP and the substrate (increasing $K_{m}$ ), while kaolinite increases the affinity between LAP and the substrate (decreasing $K_{m}$ ). It should be noted that clay minerals can increase the inhibition ratio of Cd on purified LAP. The interaction between leucine aminopeptidase, clay minerals, and cadmium contamination in the soil is a complicated process that is related not only to the concentration of the three but also to the soil environment. Therefore, the process and mechanism by which clay minerals affect the toxicity of Cd to LAP are still unclear. 
In consequence, it is important to continue to study the interaction between clay minerals, Cd and LAP, and the inhibition mechanism of $\mathrm{Cd}$ on clay mineral-immobilized LAP. This can provide scientific evidence for restoring the activity and function of LAP in Cd-contaminated soils and to provide some help in restoring nutrient use efficiency and accelerating nutrient cycling in contaminated soils.

\section{Data Availability}

The data that support the findings of this study are available from the corresponding author upon reasonable request.

\section{Conflicts of Interest}

The authors do not declare any conflict of interest.

\section{Acknowledgments}

This research was supported by the National Natural Science Foundation of China (41701288) and State Key Laboratory of Geohazard Prevention and Geoenvironment Protection Independent Research Project (SKLGP2018Z004).

\section{Supplementary Materials}

Supplementary tables. Table S1: soils properties. Table S2: clay minerals properties. Table S3: types of inhibition of purified LAP by Cd, Ag, and Hg. Table S4: types of inhibition of LAP in red soil by $\mathrm{Cd}$, Ag, and $\mathrm{Hg}$. Table S5: types of inhibition of LAP in purple soil by Cd, Ag, and Hg. Supplementary figures. Figure S1: SEM of (a) montmorillonite and (b) kaolinite. Figure S2: inhibition rate of purified LAP by different concentrations of $\mathrm{Cd}, \mathrm{Ag}, \mathrm{Co}, \mathrm{Mn}, \mathrm{Mg}$, and $\mathrm{B}$. Figure S3: inhibition rate of red soil LAP by different concentrations of $\mathrm{Cd}, \mathrm{Ag}$, Co, Mn, Mg, and B. Figure S4: inhibition rate of purple soil LAP by different concentrations of $\mathrm{Cd}, \mathrm{Ag}, \mathrm{Co}, \mathrm{Mn}, \mathrm{Mg}$, and B. (Supplementary Materials)

\section{References}

[1] S. Caeiro, M. H. Costa, T. B. Ramos et al., "Assessing heavy metal contamination in Sado Estuary sediment: an index analysis approach," Ecological Indicators, vol. 5, no. 2, pp. 151-169, 2005.

[2] S. M. Rodrigues, N. Cruz, C. Coelho et al., "Risk assessment for $\mathrm{Cd}, \mathrm{Cu}, \mathrm{Pb}$ and $\mathrm{Zn}$ in urban soils: chemical availability as the central concept," Environmental Pollution, vol. 183, pp. 234242, 2013.

[3] M. Rizwan, S. Ali, M. Adrees et al., "A critical review on effects, tolerance mechanisms and management of cadmium in vegetables," Chemosphere, vol. 182, pp. 90-105, 2017.

[4] J. Cui, W. Wang, Y. Peng et al., "Effects of simulated Cd deposition on soil Cd availability, microbial response, and crop Cd uptake in the passivation-remediation process of Cd-contaminated purple soil," Science of the Total Environment, vol. 683, pp. 782-792, 2019.

[5] Y. Zhu, C. Liu, Y. You, J. Liu, Y. Guo, and J. Han, "Magnitude of the mixture hormetic response of soil alkaline phosphatase can be predicted based on single conditions of $\mathrm{Cd}$ and $\mathrm{Pb}$," Ecotoxicology, vol. 28, no. 7, pp. 790-800, 2019.
[6] R. L. Sinsabaugh, B. H. Hill, and J. J. Follstad Shah, "Ecoenzymatic stoichiometry of microbial organic nutrient acquisition in soil and sediment," Nature, vol. 462, no. 7274, pp. 795798, 2009.

[7] R. G. Burns, J. L. DeForest, J. Marxsen et al., "Soil enzymes in a changing environment: current knowledge and future directions," Soil Biology \& Biochemistry, vol. 58, pp. 216-234, 2013.

[8] J. Gans, M. Wolinsky, and J. Dunbar, "Computational improvements reveal great bacterial diversity and high metal toxicity in soil," Science, vol. 309, no. 5739, pp. 1387-1390, 2005.

[9] M. A. Rao, R. Scelza, F. Acevedo, M. C. Diez, and L. Gianfreda, "Enzymes as useful tools for environmental purposes," Chemosphere, vol. 107, pp. 145-162, 2014.

[10] C. Cepeda, F. Sotres, and D. Bello, "Use of enzyme activities to monitor pollution of agricultural land," EQA-International Journal of Environment Quality, vol. 22, pp. 15-24, 2016.

[11] P. Nannipieri, C. Cepeda, and R. Dick, "Soil enzyme activity: a brief history and biochemistry as a basis for appropriate interpretations and meta-analysis," EQA-International Journal of Environment Quality, vol. 22, pp. 15-24, 2018.

[12] P. Zhang, C. Qin, X. Hong et al., "Risk assessment and source analysis of soil heavy metal pollution from lower reaches of Yellow River irrigation in China," Science of The Total Environment, vol. 633, pp. 1136-1147, 2018.

[13] S. P. Deng and M. A. Tabatabai, "Cellulase activity of soils: Effect of trace elements," Soil Biology \& Biochemistry, vol. 27, no. 7, pp. 977-979, 1995.

[14] R. D'Ascoli, M. A. Rao, P. Adamo et al., "Impact of river overflowing on trace element contamination of volcanic soils in South Italy: part II. Soil biological and biochemical properties in relation to trace element speciation," Environmental Pollution, vol. 144, no. 1, pp. 317-326, 2006.

[15] E. Smolders, K. Oorts, P. Van Sprang et al., "Toxicity of trace metals in soil as affected by soil type and aging after contamination: using calibrated bioavailability models to set ecological soil standards," Environmental Toxicology and Chemistry., vol. 28, pp. 1633-1642, 2009.

[16] A. Karaca, S. C. Cetin, O. C. Turgay, and R. Kizilkaya, Soil Heavy Metals: Effects of Heavy Metals on Soil Enzyme Activities, Springer Berlin Heidelberg, Berlin, 2010.

[17] R. G. Burns, "Enzyme activity in soil: location and a possible role in microbial ecology," Soil Biology and Biochemistry, vol. 14 , no. 5, pp. 423-427, 1982.

[18] H. Aponte, P. Meli, and B. Butler, "Meta-analysis of heavy metal effects on soil enzyme activities," Science of the Total Environment., vol. 737, pp. 1-12, 2020.

[19] R. G. Burns, Interaction of Enzymes with Soil Mineral and Organic Colloids: Interactions of Soil Minerals with Natural Organics and Microbes, American Society of Agronomy, 1986.

[20] T. Tietjen and R. G. Wetzel, "Extracellular enzyme-clay mineral complexes: enzyme adsorption, alteration of enzyme activity, and protection from photodegradation," Aquatic Ecology, vol. 37, no. 4, pp. 331-339, 2003.

[21] F. Rakhsh and A. Golchin, "Carbohydrate concentrations and enzyme activities as influenced by exchangeable cations, mineralogy and clay content," Applied Clay Science, vol. 163, pp. 214-226, 2018.

[22] Q. Huang, J. Zhu, X. Qiao et al., “Conformation, activity and proteolytic stability of acid phosphatase on clay minerals and 
soil colloids from an Alfisol," Colloids Surf B Biointerfaces, vol. 74, no. 1, pp. 279-283, 2009.

[23] A. R. Zimmerman and M. Y. Ahn, Soil Enzymology: OrganoMineral-Enzyme Interaction and Soil Enzyme Activity, vol. 15, pp. 271-286, Springer Berlin Heidelberg, Berlin, 2011.

[24] J. E. Coleman, "Structure and mechanism of alkaline phosphatase," Annual Review of Biophysics and Biomolecular Structur, vol. 21, pp. 441-483, 1992.

[25] C. Pan, H. D. Liu, and Z. Gong, "Cadmium is a potent inhibitor of PPM phosphatases and targets the M1 binding site," Scientific Reports, vol. 3, no. 1, 2013.

[26] R. Zalaghi, M. N. Masirm, and A. Moezzi, "Effects of Cd on soil microbial biomass depend upon its soil fraction distribution," Toxicological \& Environmental Chemistry, vol. 101, no. 9-10, pp. 486-496, 2019.

[27] Z. Yang, Y. Liao, X. Fu, J. Zaporski, and S. Peter, “Temperature sensitivity of mineral-enzyme interactions on the hydrolysis of cellobiose and indican by $\beta$-glucosidase," Science of the Total Environment, vol. 686, pp. 1194-1201, 2019.

[28] P. Liu, S. Chen, and Y. Cui, "Insights into the inhibition effects of Cd on soil enzyme activities: from spatial microscale to macroscale," Journal of Hazardous Materials, vol. 418, no. 9, p. 126274, 2021.

[29] S. Brunauer, P. H. Emmett, and E. Teller, "Adsorption of gases in multimolecular layers," Journal of the American Chemical Society, vol. 60, no. 2, pp. 309-319, 1938.

[30] A. U. Dogan, M. Dogan, and M. Onal, "Baseline studies of The Clay Minerals Society source clays: specific surface area by the Brunauer Emmett Teller (BET) method," Clays and Clay Minerals, vol. 54, no. 1, pp. 62-66, 2006.

[31] J. L. DeForest, "The influence of time, storage temperature, and substrate age on potential soil enzyme activity in acidic forest soils using MUB-linked substrates and L-DOPA," Soil Biology \& Biochemistry, vol. 41, no. 6, pp. 1180-1186, 2009.

[32] J. Wang, S. Huang, Q. He et al., "Microplate fluorimetric assay of soil leucine aminopeptidase activity: alkalization is not needed before fluorescence reading," Biology and Fertility of Soils, vol. 56, no. 2, pp. 281-285, 2019.

[33] N. Straeter and W. N. Lipscomb, “Two-metal ion mechanism of bovine lens leucine aminopeptidase: active site solvent structure and binding mode of L-leucinal, a gem-diolate transition state analog, by X-ray crystallography," Biochemistry, vol. 34, no. 45, pp. 14792-14800, 1995.

[34] G. F. Bryce and B. R. Rabin, "The function of the metal ion in leucine aminopeptidase and the mechanism of action of the enzyme," The Biochemical journal, vol. 90, no. 3, pp. 513$518,1964$.

[35] S. R. Himmelhoch, "Leucine aminopeptidase: a zinc metalloenzyme," Archives of Biochemistry and Biophysics, vol. 134, no. 2, pp. 597-602, 1969.

[36] N. S. Punekar, Enzymes: Catalysis Kinetics and Mecechanisms: Origins of Enzyme Catalytic Power, vol. 6, pp. 60-62, Blackie Academic \& Professional, Springer Nature Singapore, 2018.

[37] S. Y. Bhat and I. A. Qureshi, "Structural and functional basis of potent inhibition of leishmanial leucine aminopeptidase by peptidomimetics," ACS Omega, vol. 6, no. 29, pp. 1907619085, 2021.

[38] V. Acosta-Martínez and M. A. Tabatabai, "Arylamidase activity in soils: effect of trace elements and relationships to soil properties and activities of amidohydrolases," Soil Biology \& Biochemistry, vol. 33, no. 1, pp. 17-23, 2001.
[39] V. Acosta-Martínez, Arylamidase Activity of Soils: Part II. Arylamidase Activity of Soils, Iowa State University, America, 2000.

[40] W. A. Dick, "Method of soil enzymeology: kinetics of soil enzyme reactions," American Society of Agronomy, Crop Science Society of America, and Soil Science Society of America, vol. 3, pp. 57-69, 2011.

[41] X. Tan, L. Kong, and H. Yan, "Influence of soil factors on the soil enzyme inhibition by Cd," Soil \& Plant Science, vol. 64, pp. 666-674, 2014.

[42] K. Shah and R. S. Dubey, "Cadmium elevates level of protein, amino acids and alters activity of proteolytic enzymes in germinating rice seeds," Acta Physiologiae Plantarum, vol. 20, no. 2, pp. 189-196, 1998.

[43] A. G. Caporale and A. Violante, "Chemical processes affecting the mobility of heavy metals and metalloids in soil environments," Current Pollution Reports, vol. 2, no. 1, pp. 15-27, 2016.

[44] S. D. Young, Heavy Metals in Soils: Chemistry of Heavy Metals and Metalloids in Soils, vol. 3, pp. 51-97, Blackie Academic \& Professional, Springer Dordrecht Heidelberg New York London, 2013.

[45] X. Y. Guo and S. Z. Zhang, "Characterization of $\mathrm{Pb}, \mathrm{Cu}$, and Cd adsorption on particulate organic matter in soil," Environmental Toxicology and Chemistry, vol. 25, no. 9, pp. 23662373, 2006.

[46] J. G. Wang and J. L. Lv, "Effects of organic acids on Cd adsorption and desorption by two anthropic soils," Frontiers of Environmental Science \& Engineering, vol. 7, pp. 19-30, 2013.

[47] M. Shirvani, B. Khalili, and M. Kalbasi, "Adsorption of alkaline phosphates on palygorskite and sepiolite: a tradeoff between enzyme protection and inhibition," Clays and Clay Minerals, vol. 68, pp. 287-295, 2020.

[48] M. A. Rao, A. Violante, and L. Gianfreda, "Interaction of acid phosphatase with clays, organic molecules and organo- mineral complexes: kinetics and stability," Soil Biology and Biochemistry, vol. 32, no. 7, pp. 1007-1014, 2000.

[49] R. Datta, S. Anand, A. Moulick, D. Baraniya, S. I. Pathan, and K. Rejsek, "How enzymes are adsorbed on soil solid phase and factors limiting its activity: a review," International Agrophysics, vol. 31, pp. 287-302, 2017.

[50] D. Dodor, H. Hwang, and S. Ekunwe, "Oxidation of anthracene and benzo[a]pyrene by immobilized laccase from Trametes versicolor," Enzyme and Microbial Technology, vol. 35, no. 2-3, pp. 210-217, 2004.

[51] B. P. Kelleher, A. J. Simpson, and O. K. Willeford, “Acid phosphatase interactions with organo-mineral complexes: influence on catalytic activity," Biogeochemistry, vol. 71, no. 3, pp. 285-297, 2004.

[52] T. Fiorito, I. Icoz, and G. Stotzky, "Adsorption and binding of the transgenic plant proteins, human serum albumin, $\beta$-glucuronidase, and Cry3Bb1, on montmorillonite and kaolinite: Microbial utilization and enzymatic activity of free and claybound proteins," Apply Clay Science, vol. 39, no. 3-4, pp. 142-150, 2008.

[53] Z. Q. Wang, Y. B. Li, X. P. Tan et al., "Effect of arsenate contamination on free, immobilized and soil alkaline phosphatases: activity, kinetics and thermodynamics," European Journal Of Soil Science, vol. 68, no. 1, pp. 126-135, 2017. 